NBER WORKING PAPER SERIES

\title{
GLOBALIZATION, TRADE, AND DEVELOPMENT: SOME LESSONS FROM HISTORY
}

\author{
Alan M. Taylor \\ Working Paper 9326 \\ http://www.nber.org/papers/w9326 \\ NATIONAL BUREAU OF ECONOMIC RESEARCH \\ 1050 Massachusetts Avenue \\ Cambridge, MA 02138 \\ November 2002
}

This paper was prepared for the IDB-Brookings Conference on Regional Integration And Trade, Washington, D.C., May 31-June 1, 2001. For helpful comments I thank Susan Collins, Robert Devlin, Antoni Estevadeordal and conference participants. The usual disclaimer applies. The views expressed herein are those of the authors and not necessarily those of the National Bureau of Economic Research.

(C) 2002 by Alan M. Taylor. All rights reserved. Short sections of text, not to exceed two paragraphs, may be quoted without explicit permission provided that full credit, including $(\mathcal{C}$ notice, is given to the source. 
Globalization, Trade, and Development: Some Lessons From History

Alan M. Taylor

NBER Working Paper No. 9326

November 2002

JEL No. F02, F10, N00, N70, O10

\title{
ABSTRACT
}

Recent research in international economic history has opened up new lines of enquiry on the origins of globalization, as well as its causes and consequences. Such findings have the potential to inform contemporary debates and this paper considers what lessons this body of historical work has for our current understanding of the linkages between trade and development.

\author{
Alan M. Taylor \\ Department of Economics \\ University of California \\ One Shields Avenue \\ Davis CA 95616 \\ and NBER \\ amtaylor@ucdavis.edu
}




\section{Globalization and the Long View}

On the eve of the sixteenth century, with very little fanfare and a perilously small fleet, a man from Genoa by way of Portugal and Spain, displaying reckless ignorance of the course ahead, embarked on a voyage of chance that presaged a global future of political and economic turbulence, with all the conquest and co-operation, prosperity and inequality that have defined the modern world. As the twenty-first century dawned, accompanied by considerably more fanfare and a great flotilla including an even oceangoing liner, the world's leaders sailed into Genoa from all corners of the globe—but, with accusations of reckless ignorance traded on both sides, they were greeted by an equally cosmopolitan mass of protesters, occasioning some of the most violent, and the first fatal, anti-global demonstrations to date.

Not without irony, not for the first time, though rarely before with such instantlycommunicated mass impact, the 2001 G- 8 summit raised the question as to how we understand and cope with the forces of globalization set in motion five centuries before. The Genoese gave us Columbus, and though proud of their favorite son, they were probably amazed or baffled by his quest, and certainly unaware of the ultimate global impact of his endeavor; amazed or baffled again as the global consequences swirled around them on the same waterfront 500 years later, they were surely reaping far more than they had sown, and probably felt, like many of the discontents and doubters, that they were just an unwilling bit part caught up in a larger drama of powerful force.

Economic history is embellished by such anecdotes and reflections, but at the business end, in its art and its science, the search causal connections, documentary evidence, and persuasive argument often proves more elusive than finding the storytelling hooks. Only when the theory, and the evidence, and the story fit is the work complete, and an analytic narrative established. To try to succeed in all three areas is equal parts courageous and foolish. Compounding the risk, the aim of this paper is to survey the history of globalization from 1500 to the present, and so illuminate the key economic characteristics of the modern world. In this essay I try to step back from a focus on the immediate present and ask what the longer sweep of history can tell us about globalization, with special reference to issues of trade and development.

Current economic challenges have not arisen out of nowhere and they have plentiful antecedents. Is economic divergence inevitable in a globalized economy? Will trade promote inequality? Will migration pressures increase? Are open capital markets destined to lurch from crisis to crisis? If states cannot stop this process, can they even hope to contain it? Should they? At a deeper, less tractable, but more fundamental level, can nations adjust not just economically but also socially, culturally, and ideologically, to the challenges posed by a wider world perched on their economic doorstep? The economic historian contends that these questions cannot be fully answered by pure introspection 
and a recourse to abstract theory, or the analysis and debate of present-day events. All of these challenges were faced by towns, cities, regions, states, and nations in the past.

Responses varied. Sometimes the outcomes were positive, sometimes not. Such variation is of inestimable value to the social scientist: it is our only empirical evidence of the globalization and the variation represents the closest thing to an experiment, controlled or otherwise, in the global economic laboratory.

\section{The Modern World: Globalization and Its Discontents}

Globalization is nothing new. One might be forgiven for thinking otherwise, since so much recent popular writing declares in sensational tones that a revolution is afoot. The time frame of many popular, and some academic and policy studies, tends to be a few years at most. Conclusions and policy recommendations assume that recent globalization trends have ushered in a brave new world. The only battleground seems to be the question of whether this is a good or bad thing.

According to the early alarmism of anti-globalists, like William Greider (One World, Ready or Not) or John Gray (False Dawn), we subjects of globalization only dimly perceive the economic juggernaut that is rolling over us - and we are hopelessly illequipped for the devastating transformation it is wreaking because we have seen nothing like it before. In the view of Naomi Klein (No Logo) or George Monbiot (The Captive State) globalization threatens some combination of state weakness and corporate power that will weaken democracy and unleash greater inequality, and even authors apparently sympathetic to capitalist organization like Noreena Hertz (The Silent Takeover) wonder if there should be another way. Meanwhile a few ardent neoliberal supporters like Economist correspondents John Micklethwait and Adrian Wooldridge (A Future Perfect) have trenchantly defended and cheered globalization, garnering an endorsement from Tom Peters that hails globalization as the "most powerful—and life-enhancing — force on earth."

It is open to question whether the experience of the past decade or two fully equips us to answer all the questions raised by globalization and its discontents. A rapidly growing field of new comparative economic history is only now starting to grapple with these issues, but already we can survey some important findings of very recent literature. With that background I will attempt to address some key concerns about trade and globalization, especially in developing countries, as follows:

- Economic fundamentals. When and how did the constraints of scarcity and the desire to trade take hold? Are such forces as powerful now as in the past?

- Institutional bases. Trade never existed in an institutional vacuum. Important developments in legal, contractual and financial systems made a difference. What do those events say about the limits on participation in trade today?

- Technological shocks. Revolutions in transport and communications spurred trade. Do serious transportation-cost constraints still inhibit development? 
- Patterns of exchange. Exchange occurs not only in goods, but in factor markets and in technology. How have these interacted in history? What does that say about the possible substitutability of trade and other forms of integration today?

- Human welfare. What have been the impacts of past globalization trends on prices, risk, living standards, and income distribution? What does that say about the costs and benefits of globalization today?

- Political economy. Globalization suffers the constraints of, and imposes constraints on, national economic policies. How has that tension been addressed in the past? How does that speak to the future?

It first bears observing that the recent trend towards a convergence in global markets will not necessarily yield an inevitable "End of History," as Francis Fukuyama (1992) called the even broader process of global convergence in many spheres, economic, social, political and cultural. Indeed, recent events seem closer to Samuel Huntington's brush with futurism, "Clash of Civilizations." But even when first proposed the "End of History" idea had a distinctly ahistorical feel. The idea had first emerged at the end of the nineteenth century, as the last great wave of globalization reached its peak. The view was soon discredited after 1913 as globalization receded in the twentieth century turmoil of wars, depressions, and the erratic course of economic policies and political philosophies (Angell 1910).

As is now widely recognized, and as is largely taken for granted in this paper, only in the last few years has the world made progress toward, and arguably beyond, the degree of globalization seen a century ago. Can this trend continue, or will it face diminishing returns or even a much talked-about backlash? And what does history have to say about how we got here? To set the stage, just consider two benchmarks for the degree of international market integration "then" versus "now" in two markets, goods and capital. ${ }^{1}$ Figure 1 shows the ratio of world trade to world GDP since 1800 at key benchmark dates and the conclusion is clear: after a continuous rise during the $19^{\text {th }}$ century, trade peaked in 1913 as a fraction of world economic activity, slumped during most of the middle $20^{\text {th }}$ century, and has revived recently, though to levels no higher than those witnessed a century ago. Figure 2 shows the ratio of world stocks of foreign investment to GDP over roughly the period since 1870 (data back to 1800 are incomplete, but we would guess the ratio to be about 0.1 at that point). A similar message emerges: after peaking around 1913, the global capital market was almost quiescent for the next sixty or seventy years, before renewed activity in the 1980s and 1990s. ${ }^{2}$

\footnotetext{
${ }^{1}$ It goes without saying that labor markets are now much more restricted than a century ago, as migration is tightly controlled. This is not to say that, despite such controls, the incentives to migrate in today's world of massive international income gaps do not lead to large population movement, legal or otherwise, despite such obstacles. See Chiswick and Hatton (2002).

${ }^{2}$ In each case the data is for selected countries for which data are available. See the discussion in the original papers, Estevadeordal, Frantz, and Taylor (2003) and Obstfeld and Taylor (2003).
} 


\section{The Rise and Fall of Globalization: Flesh Versus Spirit}

Various ingredients have developed over past centuries, and the present and past structures of economic globalization represent a particular and time-specific alignment of these forces. At the risk of oversimplification, an overview of this evolution of the world economy as I will describe it is presented in Figure 3, and the story is cast as an interplay between two kinds of forces: the economic and technological forces versus the political and institutional forces.

On the vertical axis are the economic and technological forces that may promote economic globalization via market integration, including the ability to transport goods or communicate information across distances at higher speed and lower cost. These tangible and physical elements I label "flesh." They include new shipping or power technologies, such as steam engines used in ships and trains, as well as new and better communication devices such as the telegraph, telephone, or internet.

On the horizontal axis are the political and institutional forces that may reinforce or inhibit said globalization. I call these "spirit" as a reference to the intangible quality of the underlying thinking in which the tangible market mechanisms are embedded. At the simplest level one can think here of trade policies, capital controls, immigration restrictions affecting markets for goods and factors; but this dimension also includes a broader array of legal and customary devices that provide public goods such as the security of property rights, contract enforcement, stable and predictable monetary and fiscal policies, and freedom from bribery, corruption, or the diversion of resources through rent-seeking. According to this schema, and in agreement with the view that the twentieth century has been on the whole an aberrant period of de-globalization, the depiction in the figure claims that the history of the world economy has been far from linear, and if anything somewhat circular. But we must set aside any temptation to get Hegelian: we have not come full circle, nor are we likely to.

The world begins, for these purposes, in the upper left cell of the matrix in the distant past, with both types of forces operating only weakly to promote globalization. The technologies for integrating markets were rudimentary and the political and institutional umbrellas covering trade were flimsy; as a result it simply cost too much (or risked too much) to move goods or factors between distant locations. By the sixteenth and seventeenth centuries, some of these forces had begun to shift, but I choose to emphasize the institutional and political changes over the technological at this juncture: a movement from the top left to the top right cell in the matrix. Transport and navigational technologies had improved very little, with dogged persistence rather than innovation permitting the fledgling opening of trade between the continents. But institutional bases for trade did change.

The experience of this initial period, and era of what one hesitates to call protoglobalization, was by no means uniform, and significant developments in the relationship between states and markets conditioned the evolution of commerce and economic growth in different locations. The big story, which scholars have explored in detail, is obviously the rise of European trading nations and the increasing geographical scope of their 
activities, usually under state protection. In the Americas these adventures encountered no incumbents, and in the waters and ports of Asia they increasingly crowded out local merchants and vessels. There was a marked penetration of the Chinese long distance trade on certain routes, an incursion that some have traced back to the failure of the Chinese to develop their merchant ambitions after the remarkable feats of the treasure fleet (Findlay and O'Rourke 2002).

Since the economic distances between markets remained large, there was only a very slow increase in the level of trade and prices in different locations were highly dispersed. But this trade flourished under very different auspices than the early trade, with an increasing role for the state, especially powerful European states that embarked on imperial adventures with trading companies in tow. As trade followed the flag it did so with the benefit of an increasingly pro-economic state structure of legal protection, financial and macroeconomic stability, and limited government predation.

One might think here primarily of the state supported trading companies like the British and Dutch East India companies, each an exemplar of this new involvement of the state in protecting commerce. Beyond these near monopolies, however, the general extension of states' economic interests beyond their own borders became an increasingly important element of government objectives, diplomacy, and legal innovation. In addition to the military-principally naval—strength to make this endeavor feasible, the whole exercise rested on a significant change in state orientation.

By the eighteenth century Britain had eventually overtaken her continental rivals as the key entrpôt in Europe, and the country eventually built up a huge flow of invisible earnings from shipping and merchant services. Early industrialization in the $18^{\text {th }}$ century, a force of the "flesh" would soon feed into this mercantile structure to propel greater specialization and a boom in trade. But even before that the reforms of 1688 propelled institutional changes in the "spirit" of the economy that undergirded the expansion of external commerce.

First, the revolution in the British fiscal state steadied the macroeconomy and laid the foundations of a modern financial sector: since merchants relied on financial techniques to conduct trade over long distances with credit, they gained. Second, a new and broader franchise in parliament kept the legal and regulatory incursions of the state on business in check, with contracts and banking activities free to develop, even after episodic financial crises and downturns. Third, although the fiscal state required stronger tax tools, these were not deployed as heavy tariffs in such a way as to crush trade; fiscal power did not equate exactly with unbridled mercantilism in this sense. Tariffs could be kept low if mercantilism was pursued by military means, by taking trade market share from rivals by force-so as to expand the tax base rather than raising the tax rate. Fourth, another centerpiece of mercantilism, the state-chartered trading companies were increasingly exposed to competition as their "patents" expired. Government was over time less inclined to view the concentration of trade in the hands of one privileged company as a desirable arrangement, and in due course a large array of commercial ventures took 
shape, increasing competition, hence the quantity of trade and again, fortuitously, the government's tax base. ${ }^{3}$

Thus I depict the early modern period, international and interregional trade was supported by increasingly pro-commercial regimes, as shown in Figure 3. This was a fundamental change in the political economy of the era, in the philosophical spirit of the age. There were limits to this change, with only a gradual dissolution of the large state-sanctioned monopoly ventures and the gradual rise of private commerce through smaller-scale enterprises. In addition, even at this more competitive level, trade remained largely canalized and often traveled under a given flag according to whichever navy controlled the shipping lanes. Accordingly, trade expended-faster than population, and faster than output-but it still remained small in the world as w whole. Whereas the spirit was now somewhat willing, the flesh was still quite weak-shipping technology was such that the benefits trade, for most commodities, did not outweigh the costs. The world trade routes were mere skeletons compared to their current form, and only cheaper transportation would add substantial flesh to those bones.

These developments set the springboard for globalization, but the big jump was yet to come. As I discuss below, the dawn of the long nineteenth century brought an end to this particular configuration of globalization. After the European powers reached a peace treaty of 1815 , the seas were open again to trade, backed now by very strong economic and technological impulses. The Industrial Revolution implied specialization wherever it spread - and equally, where it didn't — as countries traded among themselves, exchanging manufactures for primary products and vice versa. This was a fundamental international division of labor that had not been seen before on such a scale, and it also heralded the Great Divergence of incomes and productivity in the last two centuries.

Now the economic forces, the flesh in Figure 3, were aligned with the spirit, promoting a boom in global economic interaction. Besides impelling countries to abandon notions of self-sufficiency and embrace specialization via trade, the modern era also brought with it technologies, such as steam power and the telegraph, that were bound to reduce the time and cost of linking markets. Jointly, these fundamentals encouraged an amplification of international linkages by an order of magnitude over what had been seen before, either measured by convergence of prices or the surge in trade volumes.

The twentieth century, since 1914 at least, was a time when globalization went into reverse and, depending on the location and markets in question, some if not all of the gains of the nineteenth century were lost. Clearly, this was not due to our having forgotten any of the important technological innovations that spurred trade; nor was it for want of any new such innovations, since there were many, including internal combustion engines, jet air transport, and advanced electronic communications.

All of the retreat in globalization can, of course, be attributed to the political and institutional dimension of the diagram: a choice to stop the integration of markets given

\footnotetext{
${ }^{3}$ This paragraph draws extensively on the excellent survey by O'Brien (1998).
} 
the existing technological capacity to make them flourish, a weakening in the spirit of globalization, so to speak. These limits on trade have been seen as a "backlash" although their origins in two world wars can also be seen as the collateral damage of global international conflicts in an era of total war. Either way, the historical process of globalization has not been one of ever-closer union among countries, at least on this timescale.

Looking ahead, and beyond the twentieth-century experience, do we again face a choice of whether to embrace or restrain globalization? To some degree we do. But can we suppose, after several centuries of experience, that the forces that gradually coalesced to make us traders at the local, national, and then global levels will ever go away? If the genie is out of the bottle then economic globalization, in one form or another, is here to stay. But how we manage it, for better or for worse, remains a crucial and ongoing problem, a challenge that can be faced with greater confidence if we can remember, and then learn from, our centuries of experience with these issues.

\section{The Impulse to Trade: Globalization Past and Present}

To justify the division of history implied by our schema we must first address two overarching questions: What fundamental economic forces have led the world toward globalization? And when did such forces begin to operate on a scale large enough to make a difference? These questions matter not simply because they will focus our attention on historical episodes that are globalized enough to be relevant for contemporary comparison. By paying attention to historical eras in which globalization did not exist, we can also identify key characteristics that restrain market integration and mute its impact. Studying the latter type of scenario is likely to be helpful as we examine some developing countries today which globalization seems to have passed by.

At a fundamental level, economic historians are concerned with the deep human impulse to trade in all its forms: the desire to exchange goods, to imitate technology, to lend and borrow, and to migrate. Archeological evidence reveals the commonly observed and ageold proclivity of humans to "truck and barter"-in Adam Smith's felicitous phrase. This offers a flavor of the persistence of markets across vast expanses of time, but without more detailed evidence on the extent of those markets across space, we remain ill equipped to decide whether globalization has been a force for decades, centuries or millennia.

\section{When Did Globalization Begin?}

It might seem surprising that such a debate is open in the historical literature, but between repeated appeals to assertion and the difficulty of adducing archival evidence, we are only recently getting to grips with this question. For the most part, however, the debate 
might be reasonably whittled down to a battle between three camps, or, equally, three rival dates for the onset of a global economy. ${ }^{4}$

Various scholars in the world history school posit a very early start date for globalization, circa 1000. According to this view, overland and Mediterranean trade flourished in this period, with caravans and coastal shipping linking Asian and European markets, and this is enough to prove the existence of a world economy. A more conservative wing of the world history school would lean toward circa 1500 (maybe even 1492, to be precise) as the key date. This might seem more reasonable if one takes the view that a solution to the economic disconnect between the Americas and the rest of the world is a sine qua non for a global economy. Only following the voyages of discovery and the first

circumnavigation, expeditions which had at least a partial economic motive, could world trade finally span the Old and New Worlds.

Yet just because such trading links existed does not, of course, imply that they mattered fundamentally for economic outcomes. Indeed, early trade between these locations was minuscule compared to the size of these economies, and compared to the commerce on shorter routes such as the coastal European routes between the Atlantic, Mediterranean, and Baltic entrepôts. High transport costs, inadequate finance and insurance, risks of predation by pirates or potentates, and a fear of natural peril discouraged traders from transoceanic arbitrage. Only a few fearless, foolish, or well-equipped private merchants could flourish in such a setting. Of course, the newly emerging state-sponsored multinational trading companies enjoyed smoother sailing under imperial protection. That such trade existed at all, despite such risks and costs, speaks to the impulse to trade: the divergence in the relative scarcity of goods in different locations. Thus, pepper, spices, cottons, tea, coffee, and other luxury commodities were shipped out of Asia. Silver and manufactures were sold by Europe. Sugar and tobacco were the principal exports of the Americas.

Importantly, all these trades carried very high markups between export and import markets, a gap in autarky prices that created a profit sufficient to offset all the costs of transport and the risks. But the vast majority of goods had such low profit that they never traded at all. A global economy could not be said to exist, say, on the basis of a few luxury goods changing hands. These goods were a small fraction of the output of the eastern economies, and in consumption they mattered only to a rich elite in Europe. In both places, the vast majority of individuals lived near subsistence and they produced and consumed food, clothing, and shelter that moved in a tightly delimited local orbit, and certainly did not move at the global scale. Even as late as 1820 , as measured in value terms, about 99 percent of the goods produced in the world never entered trade at all (Maddison 1995). Accordingly, we may follow recent scholarship in dating any widespread impact of economic globalization-defined as economic interaction beyond trade in a few goods and a small range of locations-as occurring sometime after 1800.

\footnotetext{
${ }^{4}$ This section draws on O'Rourke and Williamson (2002abc) and Findlay and O'Rourke (2002).
} 
With the Industrial Revolution all this was to change, though the direction of causation is far from clear. After about 1800 we observe that countries did radically specialize in manufactures or primary products, and use imports to meet consumption needs. The process began with Britain, which became a net food importer early in the nineteenth century, and spread to other industrializers. On the other hand, another group of countries pursued comparative advantage in primary products, and supplied the industrializers with food and raw materials. This division of the world was radically new and predicated on exchange. It is a division whose legacy we still grapple with: the division of the world into producers and exporters of different types of goods, into the nations of core and periphery, and, with the accompanying Great Divergence, into nations rich and poor.

\section{The Evidence}

The evolution of world trade volumes speaks of this change in regime. Over the nineteenth century the ratio of world trade to output had risen from less than two percent to around 16 percent (see Figure 1, where the trade ratio is measured as exports plus imports divided by output). Globally the growth rate of world trade volume had risen from about $1 \%$ per annum in each of the $16^{\text {th }}, 17^{\text {th }}$, and $18^{\text {th }}$ centuries to around $3 \%$ in each of the nineteenth and twentieth centuries. Since the growth rate of world output in the nineteenth century was that much slower than in the twentieth century, it was during the nineteenth century that the growth rate of trade-to-output ratios in the world reached its all-time peak. By this measure, globalization as a broadly felt phenomenon arrived in the nineteenth century.

Before 1800, just as the trade volumes were small, the large gaps in prices between exporting and importing markets also attest to the very limited integration of world markets in this earlier era. International commodity markets for Asian exports such as coffee, cloves, and pepper showed consistent five-fold to twenty-fold differences between the high European and low Asian prices from the 1580s to the 1820s. Only thereafter did prices begin systematically to converge, bringing gaps into the $3: 1$ or 2:1 range. By 1900, gaps of less than $100 \%$ and tending to zero were the norm (Figure 4).

In this respect the exotic high-value commodities joined in the same marked price convergence during the late nineteenth century that was common to a much wider range of primary products and manufactures (such as cotton, see Figure 5). Widespread commodity price convergence is one definition of globalization, and this was one correlate of the vast expansion in the range and volume of goods traded and the international division according to comparative advantage that is a hallmark of the modern world economy.

In the nineteenth century a twenty-fold expansion in world trade volumes, and a similar decline in typical commodity price gaps, marked a break from the past. More formal

\footnotetext{
${ }^{5}$ The increase was more pronounced in those regions that were the earliest and most enthusiastic in embracing the trading and specialization opportunities. British trade rose from $8 \%$ of GDP to $16 \%$ during the $18^{\text {th }}$ century (Crafts 1985); and Western Europe as a whole experienced an increase from $10 \%$ to $16 \%$ in the nineteenth century (Maddison 1995).
} 
quantitative analysis is needed on this regime change, but recent work confirms that the nineteenth-century world economy was radically different from what went before in its internal equilibrium allocation and price mechanisms. ${ }^{6}$

Increasingly Britain and other industrial nations could "import" land-land embodied in food imports-leaving the local economy free to pursue a logical specialization in activities better suited to a land-scarce region. The typical quantitative equilibrium characteristic of a closed economy thus began to be replaced with standard features found in an open economy. Local factor prices were soon heavily influenced by world goods market conditions (O'Rourke, Taylor, and Williamson 1996).

The evidence points to the post-1800 period in world history as the era when the forces of globalization were truly unleashed. This is also the era that coincides with the rapid acceleration in living standards associated with "modern economic growth" following the Industrial Revolution. The coincidence of these two events warrants further discussion below, but for now we just note that the same problems of interpretation affect both phenomena.

Scholars studying the Industrial Revolution have argued incessantly about how it happened, even whether it happened, and, especially, why it happened when and where it did. The "revolutionary" and "evolutionary" views of the Industrial Revolution argue not only about the size of the break from the past, but also the nature of causation. Was there a unique confluence of events found in Britain circa 1760 that made industrialization happen? Or were centuries of economic, political, legal, social, and institutional changes responsible in a drawn-out chain of cumulative causation? ${ }^{7}$

These same issues should lead us to consider a very broad sweep of time as we seek to identify the foundations of today's international integration. As we study globalization in history, and even as we recognize the importance of dates like 1492 and 1815, an allowance for cumulative causation requires us to also seek out important interstitial developments between the benchmark dates. In this way we can glean evidence on the full set of ingredients that, in periods and places when they were properly assembled, have allowed globalization to flourish so rapidly at certain times in the last two centuries.

An obvious lesson from the last millennium for today's policymakers in developing countries is that progress can be slow. Single cases of reform, or isolated institutional changes do not seem to have made for a dramatic switch for or against globalization in past eras. Rather the slow accrual of various fundamentals laid the basis for an expansion of trade, and the benefits that could derive from it, as we describe in the next section.

\footnotetext{
${ }^{6}$ For example, econometric evidence shows that in a country such as Britain, internal factor prices became de-linked from local factor supplies, in particular the supposedland constraint that scared Malthusians so much (O'Rourke and Williamson 2002c).

${ }^{7}$ The cumulative view favors a study of diverse pre-industrial developments such as the Magna Carta, the Glorious Revolution, the patent system, the enclosure movement, the stock and bond markets, and the like-events and features that spread over time, but eventually come together as a complete foundation for growth.
} 
History is relevant here in that many of these same fundamentals seem to be still lacking in many developing countries even today.

\section{Institutional Hurdles: Making a World Safe for Trade}

\section{Cutting a Deal and the Risks of Trade}

An economic impulse to trade is not enough to get globalization started. With few local exceptions, trade does not occur in a vacuum. This is especially clear today in many developing countries, and it was true in the past in all pre-modern economies. Of course, the form and extent of institutional development will strongly influence the level of trade, if any, that can be supported.

For example, starting an import-export business requires more than just a profitable arbitrage opportunity between two locations. Along the way, in each place, one might need to legally incorporate the business, complete paperwork, satisfy regulations, employ the legal or customary currencies in use, and pay taxes and tariffs. Trade is thus is embedded in a variety of institutional structures: legal, social, and political. Some examples help to introduce the issues and motivate our look back at history.

Consider first the problem of contract-based exchange. Many developing countries today have poor legal and contractual bases for economic exchange, such that it is extremely difficult to trade anonymously, with new counterparties, at a distance, or when payment is delayed. We can recognize precursors to this problem in the medieval trade of the Mediterranean. There traders often had to work across spatially and institutionally separate entities such as the major city-states and ports of Italy like Genoa, Naples, and Venice. Even within a city, legal shortcomings might mean that trade was not protected as well as it is under modern systems of commercial law. But between political units the extent of supranational standards and enforcement was practically nonexistent. Given such obstacles, how then could the beginnings of a world economy be traced to this period?

Recent research has emphasized that in this era important private-sector institutional developments could support some trade in equilibrium, though not necessarily the optimal level of trade (Greif 1993 and forthcoming; Greif, Milgrom, and Weingast 1994). This strand of new institutional history focuses our attention via game theory on the emergence of self-enforcing and incentive-compatible relationships between actors that can allow some of the gains from trade to be materialized. With sufficient gains at stake, trade may be supported subject to the existence of adequate and credible punishments of defectors (e.g., in the event of deviations like default). Even in dispersed commercial networks such as the Maghribi traders studied by Greif, the value of reputation and the presence of reliable enough communications, could allow traders to sanction those guilty of malfeasance and enforce contractual honesty to some degree.

On the one hand, then, this is an optimistic lesson from history for present-day scenarios in which the fear, at least for the pro-global school of thought, is that many poor nations 
today might miss out on the benefits of globalization, through political malfunction or geographic isolation or infrastructural malaise. If trade simply passes them by they will never connect to the world economy and gain any of the presumed benefits of trade. Despite such obstacles, history suggests they may still gain some of the benefits: some trade can occur even when institutions are weak. On the other hand, an equally distinguished branch of institutional history warns that although such trade may exist, it is likely to be far from optimal in the absence of a strong state that can offer better institutional foundations for exchange. In a paradox, despite the need for such strength on the part of the state, the state must be assumed not to predate on trade, but rather support it. $^{8}$

Economic historians and political scientists focus on this issue because of the shifting locus of power in medieval and early modern states. It is of interest for our purpose because changes in the political center of gravity have often accompanied changes in legal, regulatory, or ownership patterns that affect important economic units engaged in trade. Scholars have noted, for example, the important limits placed on the crown as being instrumental in promoting private economic activity. We include here the willingness of a less mercantilist state to permit freer trade without high tariffs or tight customs control, to exercise fiscal rectitude and limit erratic economic policies, or to support a banking and financial system and develop financial markets.

The history of the developments in trade and finance can be traced back many centuries. And whilst the process illustrates again the rapid changes in some of the costs associated with trade, the institutional changes along the way could not have taken place without a change in the political economy of these countries' economic systems.

This change in the "spirit" of the process I align with the realization by some states, at least the successful ones, that a mutually beneficial relationship with merchant trade and finance was an essential component in the domestic and, even more, the international success of the polity. We have remarked on this above as regards the impact on trade; but the feedback on the strength of the polity was the payback. As documented by Ferguson (2001), it is hard to deny that it was financial acumen by the political leaders, as much a technological prowess by industrialists, that helped put the British state in an imperial leadership role in the nineteenth century.

Most historical literature focuses on the domestic impact of such institutional change, but we may infer that such changes, if they mattered domestically, also breathed life into international commerce. Such linkages may be inferred, for example, in the extent to which capital market activity linking London and Amsterdam grew shortly after the Glorious Revolution with the founding of the modern stock exchanges. Such institutions laid important foundations for the commercial supremacy of the Dutch and British empires, and underscore the point that the crown's ambition may have been served in the

\footnotetext{
${ }^{8}$ Various theorists have studied the nature of such state formation, and under what conditions a benificent or predatory state may emerge from anarchy or banditry (Olson 2000; Moselle and Polak 2001). Depending on the relative power of different interest groups within the polity, such a state may take on different institutional forms, for example with respect to legal structure (Glaeser and Shleifer 2000).
} 
larger sense through important self-restraint with respect to the abuse of some key economic entities (North and Weingast 1989; O’Brien 1995; Dickson 1967; Neal 1990).

\section{Trade Follows Finance? The Problems of Payments and Currencies}

An institutional innovation such as the self-restraint of the state was keenly lacking in many pre-modern economies, and still today in some of the world's poorest countries, and, without it, it is hard to know how much trade can be supported. Yet even with this public good provided, it is still a long leap actually to put in place all of the other public and private institutional innovations that, say, built up the foundations for trade in the $17^{\text {th }}$ and $18^{\text {th }}$ centuries.

In those eras many of today's developed countries grappled with key macroeconomic problems of monetary and fiscal stability and the operation of capital markets. Only through some painful experiences were these challenges confronted. These issues may have once seemed only indirectly related to trade, but they are now considered fundamental. For developing countries today, stabilization and credit rehabilitation are the short-term goals in any crisis management scenario, and without such a platform to enable basic economic functions to be served, talk of a trade strategy seems premature.

What are the essential components of a good financial system that can support not only domestic economic activity, but exploit international gains from trade? Five key ingredients have been identified by Rousseau and Sylla (2002):

- sound public finance, an end in itself, but also historically one of the precursors to a broad-based financial systems - an active and reputable government bond market tending to pre-date the development of commercial debt and securities markets;

- a stable money, since the retardation of financial systems often results from a volatile and unreliable currency, as nominal contracting becomes ever riskier;

- the development of banks and banking, which soundly expand the narrow money base into a broader credit supply by their well-chosen use of leverage in the transformation of assets;

- the establishment of a sound central bank, which regulates the money supply and monitors the banking sector, and also creates payment clearing functions; and

- the evolution of securities markets, in which specialized institutions such as investment banks intermediate in equity and debt markets.

Such a combination of factors is indeed rare, limited to only a few developed economies today. And as late as 1914, it could be argued that only six economies had succeeded in all these dimensions: Britain, the Netherlands, the United States, France, Germany, and Japan. But whilst this association is usually pointed to as support for the finance-growth nexus, we may see it also as support for the idea that finance can promote trade. All of the countries mentioned above were significant players in the world trade of the late 
nineteenth century, and narrative histories that recount how they arrived at that position emphasize the ties between commercial and financial activity that placed a high probability on such an outcome.

One may look back to the early Renaissance with the rise of deposit banks in Florence, and the first use of paper as a substitute for gold coin by merchants. Once these instruments became negotiable, like primitive checks, they vastly simplified trade by removing the need to carry inconvenient metals that were an invitation to theft. These bills of exchange then reached the wider market for trade in Europe and the world via the spread of this innovation to the banks of Amsterdam and London, the ports and financial centers that handled a very large share of world trade at that time.

As the British economy became dominant in the eighteenth and nineteenth centuries, and as London emerged as the principal world financial center, the sterling bill rose to prominence as the world standard for international payments in trade. At the same time, financial complexity grew with the development of larger banks (such as the Wisselbank in Amsterdam or the Bank of England in London), bond markets (an innovation of a British government desperate for war finance), stock exchanges (Amsterdam and London circa 1680), and complicated financial derivative products (options were created less than a decade after the London stock exchange opened in the 1680s).

In the political economy of this symbiotic relationship between trade and finance, the market endorses the state as much as vice versa. Perhaps the most transparent and most debated of all of the financial markets' ways of "disciplining" governments remains via the currency market. An old tradition in the economic history literature here points to the role of a commitment to stable money, usually taken to mean the gold standard in the nineteenth century, as a way for governments to earn reputational benefits. As Bordo and Rockoff (1996) have demonstrated, the effect of joining gold was usually to lower country risk, thus boosting investment from overseas and promoting growth. Although gold no longer exists as a "currency standard," the same macroeconomic stability criteria still guide bond spreads in today's capital market, so that exchange-rate floaters (and the many clandestine fixers) need to pay attention to essentially the same monetary and fiscal policy fundamentals. ${ }^{9}$

There may be other beneficial results of choices that condition macroeconomic policy in an open economy environment. Just as a "currency standard" might have capital market spillovers, so too it might promote trade. As recent work by Rose (2000) and others has shown, common currencies appear to be highly significant explanators of higher trade volumes in contemporary data, boosting trade by a factor of 3 or more ceteris paribus in a gravity-model setting. Can such a large impact be believed?

\footnotetext{
${ }^{9}$ Obstfeld and Taylor (2003) expand the Bordo-Rockoff methodology to a broader sample of countries and time periods, including the interwar. They find that reputations were hard to build in the sense that country risk is highly persistent. On the other hand, the persistence drops greatly after 1914, suggesting that reputation was then frittered away; the interwar gold standard was, as many have suspected, a different animal than its prewar cousin, with considerably less confidence in the system shown by markets (and, history shows, rightly so).
} 
Historical data supply helpful corroboration here. Studies of trade and the gold standard can explore this currency-trade relationship for the significant core and periphery economies of the globalized late-nineteenth-century economy. ${ }^{10}$ The results indicate still large common-currency effects on trade. Joining the gold standard from 1870 to 1914 might have boosted trade by $30 \%-50 \%$ ceteris paribus, and by a similar amount even in the 1920 s, which is arguably a much more reasonable magnitude than the factor of $200 \%$ posited by Rose. ${ }^{11}$

This brief tour of history allows us to focus on a few points of economic significance. Public finance, and its intersection with money and fiscal policy, sets the institutional stage for international as well as domestic market transactions. Institutional change that buttresses these areas can promote growth and trade. Such institutional change might be self-strengthening, or it could be self-sacrificial, or self-disciplining, as in the case of adherence to new policy rules. A most attractive "hand-tying" exercise in the late nineteenth century relied on such a sacrifice to be rewarded by "network externality" property of the global payments system. As with a software standard, once many agents are using a particular money, everyone else will want to use the same money too to lower their transaction costs and boost trade.

Empirical evidence suggests that trade and macroeconomic policies deeply intersect on this issue and trends in recent regional and global initiatives show that the compatibility of trade and macro-finance policies is starting to be taken seriously. Fixed exchange rates are not a panacea, but the narrative evidence on the importance of currency standards like the sterling bill in early modern trade, and then the econometric evidence on the classical gold standard and contemporary common currencies, suggest that currencies do matter. Such imperatives guided the economic case for European Monetary Union, and developing countires will likely explore similar options as time goes on.

\section{Input Trade Strategies: Do-It-Yourself Comparative Advantage?}

In this section I turn to developments in the modern era and those extensions of globalization and trade that, from an historical point of view, might have mattered most for long-run economic outcomes. I take here an unusual line in that I am not going to focus on trade in final goods at all.

In some sense, this emphasis derives from a conviction that the growth-promoting effects of goods trade have been explored in endless research during the last decade, and with

\footnotetext{
${ }^{10}$ A serious objection to contemporary studies notes their reliance on a small and obscure subset of "common currency" areas in current data to generate the result (e.g. countries in the CFA Franc zone in West Africa). The inference on historical data is likely to be much more robust concerning the effects on large economies, and cleaner given that trade was less distorted by tariff and nontariff barriers.

${ }^{11}$ See Eichengreen and Irwin (1995); Estevadeordal, Frantz, and Taylor (2003); and López-Córdova and Meissner (forthcoming).
} 
little agreement about the result. ${ }^{12}$ From another vantage point it also proves to be very difficult to find any strong consensus in the historical literature concerning the impact of trade barriers on growth, absent a few recent noteworthy contributions. And even there the effects seem to often run quite counter to conventional wisdom. ${ }^{13}$

Given that the jury is still out on the question of whether protection of final goods was bad for growth, I choose to emphasize two areas where history seems to have very powerful stories to tell about constraints to growth posed by the immobility not of goods, but of factors. Conventional theories of trade and growth tell us that the availability of intermediate inputs will matter for allocation, specialization, and accumulation. These issues in one form or another face developing countries today, but they also stood as a challenge to many economies during the last era of globalization a century ago.

\section{The Resource Trade: The End of Geography?}

Globalization implies that more and more economic objects become mobile: goods in trade, people through migration, and investment via the capital market. For a long time, however, geography could still dictate the structure of economic organization at some level because one fundamental set of inputs-natural resources such as agricultural land, forestry, minerals, ores, and fuels - remained immobile even as almost everything else became transportable. Naturally, this has led to many speculations as to the geographic determinants of economic activity in general, and the Industrial Revolution in particular. According to an overly simplified version of this story, Europe, and especially countries like Britain, Germany, and France, were destined to industrialize because they were lucky enough to have the relevant raw materials, like coal and iron ore, on hand (Landes 1969; Jones 1981; Pomeranz 2000).

The later nineteenth century, however, provides us with a better range of data to formally test such a proposition. By examining disaggregated data on imports and exports, Wright (1990) was able to expose the resource-rich content of U.S. net exports during the period 1880 to 1930 . This was a crucial finding, since it was at this time that the U.S. entered a rapid growth spurt, overtaking Britain and all other nations in terms of productivity and income per capita, and the sources of that spectacular growth demand explanation. The logic here is that a resource-led switch to industrial activity (despite a historic comparative advantage in primary products) allowed the U.S. to specialize in products with faster total-factor-productivity (TFP) growth potential.

\footnotetext{
12 The case that openness promotes growth was made by numerous papers, best known being Sachs and Warner (1995). For a skeptical view, particularly on the question of whether we really a good measure openness, and whether it correlates with growth, see the response of Rodriguez and Rodrik (2000).

${ }^{13}$ For example, Vamvakidis (1997) found that economic growth in the early twentieth century was positively related to tariffs, controlling for other determinants; and O'Rourke (2000) found the same for the late nineteenth century in a small sample of countries. The consensus within economic history seems to be that these are puzzling and provocative results that warrant much more attention as we seek to confirm their robustness. Nonetheless, for now they confirm the older assertions of Bairoch (1972) that from a nineteenth-century perspective it is hard to argue that tariffs were bad for growth, especially when one considers the impressive performance in that era of such protectionist bastions as the United States.
} 
In the background here is a story of specialization driven by factor endowments, in the usual Heckscher-Ohlin style. Is such an assumption justified? The Heckscher-Ohlin theory has never worked that well when tested as a factor-content-of-trade model, but an extended, albeit indirect test of this kind of Wright's hypothesis was put forward by Estevadeordal and Taylor (2002). In the late nineteenth century, for a sample of 18 countries, they show that it was only for natural resources (both land and minerals) that the Heckscher-Ohlin theory fit reasonably well, whereas the fit was poor for labor and capital (see Figure 6). We can take this as a sign that resources were an important determinant of comparative advantage globally and not just in the United States.

However, already by the dawn of the twentieth century this argument was losing steam. Even resource endowments began to overcome the "tyranny of distance" that had pinned them down for so long. By the mid-to-late twentieth century, the lowered cost of transportation for raw materials fostered a group of Newly Industrializing Countries that had very little in the way of the necessary local resource endowments. Vast chunks of Australian terra firma are now shipped to countries such as Japan (since a major postwar trade treaty in the 1950s) and (later) to the East Asian NICs on bulk carriers. Mineral ores from remote outback regions like the Kimberley and Pilbarra now supply foreign steel plants with a vital input, and prove that, in our day and age, even mountains can be moved.

But this trade is not so universal that we can declare that resource endowments don't matter any more. In practice, they do, because not every country has established either the required infrastructure or the necessary free commercial policy to reduce domestic resource prices to "world" levels. Geography surely matters. For example, a landlocked country will be hard-pressed to access Australian ore imports as easily as Japan and the East Asian NICs did in the last fifty years: all those countries were fortunate enough to have developed have deep-water ports. Thus the significance of the "landlocked dummy" in many growth and gravity model equations seems entirely reasonable, even as we recognize that with appropriate transport developments via infrastructure investment even this constraint can be broken. Ceteris paribus, such investments would not be efficient, but given the extremely low levels of development in poor landlocked countries (and the attendant low wages) such developments could be beneficial, provided the right institutional setting is achieved.

Why should this matter for long-run outcomes? In a static model it won't, but in a dynamic model, specialization can matter for growth if countries can be "trapped" in slow-growing sectors by comparative advantage. Models such as that of Matsuyama (1992) formalize this process. In that case the intuition is that only one sector (call it "industry") has positive learning-by-doing externalities. The other (call it "agriculture") doesn't. In that setting, any factor-an agricultural revolution, a commercial policy distortion, a scarcity of minerals, an abundance of land-that promotes resources to shift out of manufactures will harm long-run growth. ${ }^{14}$

\footnotetext{
${ }^{14}$ Of course, these kinds of results are "built in": they follow from an assumption that the sectors are asymmetric, and an endogenous growth process only exists in one and not both.
} 


\section{The Capital Goods Trade: An Import-Led Growth Strategy?}

The other type of input trade that history has a great deal to say about is trade in capital goods. One strand of the recent growth literature has recognized that capital goods may be an important channel for determining growth outcomes. De Long and Summers (1991) posited the existence of differential returns for equipment investment across countries arising from differences in commercial policies and other distortions. This finding was embedded in a model by Jones (1994) where distortions on capital goods act as a tax on accumulation, and hence slow growth, and an example was made of India. The detailed econometrics of the price-investment nexus were explored by Taylor (1994; 1998ab) using the postwar price-distortion policies in Argentina as a key exemplum. In such cases, tariff policies, if they protect capital goods more than other goods (e.g. consumption goods) can create a high relative price of capital, defined as $\left[P_{K} / P_{Y}\right]$ the price of capital goods relative to GDP. This will, in turn, bias the user cost of capital upwards: even for the same interest rate, a project must yield a higher output stream to compensate for the expensive capital inputs that must be purchased locally.

Some of the variation in capital goods prices could certainly be attributed to reverse causation (low productivity) coupled with the non-tradability of capital goods (structures, for example). Still, Taylor (1998b) showed that in a cross section of countries, much of the variation in $\left[P_{K} / P_{Y}\right]$ could be explained by commercial policy and capital controls, as proxied by policy measures such as tariffs and black-market premia. This finding is consistent with a view that much capital equipment is tradable (and not just machinery and equipment — even the erecting of structures can be open to bidding from foreign firms).

Recent research that applies these insights to the last great era of globalization, only serves to strengthen this perspective on growth with tradable capital inputs. Collins and Williamson (1999) found great variation in capital goods prices from 1870 to 1939, and used these data in a similar fashion to the postwar studies to see whether capital goods prices could explain variations in investment ratios and growth. Indeed they did, and the association proves to be robust in earlier epochs. An increase of $10 \%$ in capital goods prices could lower investment ratios by roughly 5 percentage points, a large impact.

To make this point more tangible, let us consider one of the famous cases of development "failure" from this period even within the OECD, namely Australia. Once perhaps the richest economy in the world (if Maddison's data are to be believed), by the mid to late twentieth century this country had experienced negative growth relative to the OECD as a whole, and compared to the U.S. in the lead. Indeed, such was the concern over this falling back that some commentators feared an Argentine-style outcome, with regression to middle-income status (Duncan and Fogarty 1984).

In a recent paper, McLean and Taylor (2001) examined some features of the Australian case, and one fact that stands out is the coincidence of retardation from circa 1914 with a rapid increase in relative capital prices, especially as compared with other OECD countries. Figure 7 shows this change quite dramatically, and indicates that the origins of the trend can be traced back to the 1890s, a time when Australia embarked on import- 
substituting industrialization with aggressive use of tariff policy. By the 1920s and 1930s, the tariff's effects were compounded by the increase in global protectionism, leaving Australia, with no comparative advantage in machinery and equipment, facing capital goods prices that had increased by perhaps $50 \%$ as compared to the United States.

This kind of analysis of the dynamic effects of trade policy is now beginning to influence policymaking. A noteworthy recent example would be the recent decision of then Argentine finance minister Domingo Cavallo to eliminate tariffs of capital goods and raise them on consumer goods in an attempt to reinvigorate the depressed Argentine economy. ${ }^{15}$ Most likely, this policy has been overtaken for the moment by events such as the fiscal crisis of the state and the default. It will be interesting to see whether this kind of plan will inspire imitators elsewhere. If so, then policy reforms that explicitly recognize the different static and dynamic tradeoffs in the protection of consumption and capital goods could be an important area in years ahead, although it remains to be seen what kind of institutional embedding will make such changes possible.

\section{And The Winner Is...? A Long View of Political Economy and Trade}

\section{Trading Up or Trading Down? Globalization and Inequality}

Trade, according to an old pedagogical device, is best thought of as just another technology. A production process in a factory turns inputs into outputs. But so does trade: we put in exports, and what comes out are imports. But like any technology, trade is subject to constant change, shifts that can benefit some countries more than others, and some individuals more than others. A new mechanized way to produce textiles upset the Luddites (and had them breaking machines in protest); but the same irritations would have accompanied (indeed, do accompany) the sudden arrival of cheap textiles not from a new-fangled device, but simply out of the machinery of trade.

Similar technological analogies for globalization forces could easily be built around shifts in other markets, be it outflows of capital (the "giant sucking sound" made famous by Ross Perot) or inflows of immigrants (demonized for economic impacts as well as out of racial, ethnic, or cultural bias). But what are the facts? When we look at the views of either side, how accurate is their picture historically? History offers some neglected, but relevant case studies.

For example, in the nineteenth century, beginning with the repeal of the Corn Laws in Europe, the free trade movement was a radical populist movement. It sought to release Old World working classes from low wages and high food prices (and symmetrically, to "release" landlords from low labor costs and high land rents). Labor exported itself from glutted markets, either literally (by migration) or implicitly (in labor-intensive goods

\footnotetext{
15 This plan was explicitly intended to boost investment and hence growth, and attract foreign capital-exactly as the above academic research papers had argued. It was a radical plan, and not without problems since it required unilateral actions that conflicted with Mercosur commitments. Nonetheless, domestic interests have prevailed and restarting growth was seen to trump free trade area agreements.
} 
exports); in the opposite direction cheap food flooded in from the New World, an implicit import of land embodied in goods. As wages, rents, and prices adjusted, real incomes of rich and poor converged. The other side to the story, of course, is that opposite effects obtained in the trading partners. Ceteris paribus, New World wages had to decline and land rents rise, as income-distribution effects working in the reverse direction (O'Rourke and Williamson 1999).

For some guidance on whether the major shifts in globalization and trade have had any temporal or causal association with inequality, we may turn to a recent comprehensive survey paper by Lindert and Williamson (2002). These authors find that global inequality between individuals has increased over time since circa 1800, as shown in Figure 8. However, all of this change is accounted for by the rise in international rather than intranational inequality. That is, the Great Divergence of national economic outcomes has had much more to do with global inequality than have any within-country effects of changing economic factors over 200 years.

Admittedly, the data underlying these results is highly fragmentary and fragile, especially the attempt to compute global and national income distributions before 1950, and, especially, before 1900. Though built on heroic assumptions, this is still an original and important exercise in data collection and agglomeration. If we take it at face value, then the main result is, in and of itself, enough to cast doubt on many of the presumed channels through which today's critics imagine globalization exacerbates within-country inequality.

For example, if the Heckscher-Ohlin framework has validity, we should see large changes in factor rewards and hence inequality, whenever there is a major change in trading regime, for different countries have great variation in endowments. Even an allowance for differing technology levels between countries is entirely consistent with this result (Trefler 1993). Yet the vast ups and downs in world trade integration over 200 years (Figure 1), and the steady long run trend toward higher trade volumes, appear to be little correlated with shifts in within-country income distributions (Figure 8).

Similarly, we could construct arguments based on the rise and fall of international capital flows and labor migration in the nineteenth and twentieth centuries to suggest that withincountry inequality ought to have been disturbed by linkages in these markets too-when they functioned well before 1914 and when they didn't for most of the mid-twentieth century. Yet, again, the correlation isn't there. World within-country inequality did not systematically rise in the last great age of globalization, then fall during the twentieth century anti-global reaction, and then rise again. Simply put, the relationship between globalization and inequality (and certainly between trade and inequality) isn't that direct or clear cut.

There are two possible reactions to the basic evidence. One is to believe that the linkage from trade to inequality is weak or nonexistent. This, I would argue, is an erroneous conclusion. The forces appear to be quite strong and statistically significant in wellfocused historical studies that examine econometrically the links between changes in the terms of trade and change in domestic factor prices. For example, the effects appear to be 
strong for both the developed and developing world in the late nineteenth century (O'Rourke, Taylor, and Williamson 1996; Williamson 2002). It might just be that these effects, though very strong, are simply swamped in quantitative significance by changes in between-country inequality, namely the Great Divergence. That is principally the message we can take from Figure 8.

A second conclusion might be, instead, to doubt the extent to which globalization has actually been allowed to proceed to its fullest extent. Perhaps trade would change global inequality if allowed to proceed without barriers, but as yet we may doubt that it has been permitted to reach that level. Those areas of the world that did participate in the globalization of the pre-1914 era did find very radical shifts in income distribution driven by trade. In the New World, land rents rose as the land was embodied in food and exported. In Europe, the exact opposite forces were at work when the food arrived. In the former case, landowners gained, but in the latter they faced large losses in income.

Since we are concerned in this essay with the potential implications of globalization for developing countries we need to ask what specific historical precedents there are for this Heckscher-Ohlin story. It should not be imagined that such experience was limited only to a few rich countries participating in the global economy of the late $19^{\text {th }}$ century. Similar impacts of trade on income distribution were seen in both labor-rich and laborscarce developing countries of that era, in the Middle East, South Asia, and Latin America. In a labor abundant country, such as Thailand, for example, opening up to the world economy meant that the poorest laborers gained enormously as compared to the owners of scarce land, implying a dramatic leveling of the country's income distribution (Williamson 2002).

The lesson here is that when globalization forces operate, whilst in some countries they may have egalitarian impacts, in other countries they may have inegalitarian impacts (Wood 1994). However, if one can move beyond the artificial confines of a nation-state view of the world, the bottom line should be clear. Overall, globalization is one of the few forces that has offset global inequality for 200 years, with trade and factor markets allowing identical factors a better chance of earning the same reward in spatially separate locations. Those rewards might have diverged even further had spillovers from the Great Divergence in technology levels been kept more closely confined within the borders of the rich countries, yet there too global technology transfer, though imperfect and incomplete, has prevented even starker inequality; and its mechanisms undoubtedly rely on imitation and adaptation though trade links and inward investment.

Yet what might seem like good news from a global utilitarian point of view does not, of course, translate into a simple local or regional embrace of open economy policies. Policies are driven by the political economy of nation states, and even should free trade be beneficial, it will not be offer a Pareto improvement in welfare terms without redistribution. If such compensation is imperfect, winning coalitions (or minority but powerful lobbies) might be able to block any shift to more open policies.

History shows that such distributional conflicts can be a serious obstacle to trade, even under the most sympathetic circumstances. In Continental Europe, powerful landed 
interests were resistant to the "grain invasion" from the New World and successfully fought for protection, as compared to the liberal tradition in England where the landed class was once and for all defeated with the repeal of the Corn Laws in the 1840s. In the New World, owners of the abundant land resource generally could push for lower trade barriers in polities where their voices dominated political discourse (e.g., the United States South or Argentina) as compared to where it didn't (e.g., the United States North or Australia). Outcomes usually reflected this voice, the sectional clash of economic interests in the United States being a vivid intra-national example of such conflict where the battle lines were clearly drawn (Rogowski 1989).

History thus illuminates the challenges we face today, challenges that are more acute now that the "safety valve" of migration is largely closed off. Trade might ease inequality in poor countries if it allows abundant low-skilled labor an out, but it could have the opposite effect on income differentials in rich countries when that unskilled labor floods in. The trade-off depends on your world-view, whether you have a nationalistic or a global concern for income distribution or other economic objectives. The impacts also spell out clear policies to offset inequitable effects in richer countries, where low-skill workers face the severest competition from workers in developing countries: policies should aim to educate, train, or otherwise lift skill levels to differentiate local from foreign workers.

As Figure 8 shows, the far more important determinant of one's relative income level is not globalization per se, but rather the Great Divergence. The impacts of the HeckscherOhlin forces, history suggests, are in the long run of a much smaller magnitude than the massive spreads due levels of total-factor-productivity (TFP), or "technology" as we commonly say. This historically-informed perspective ought to be central to the globalization debate, but it only infrequently surfaces in political discourse, perhaps most famously in the 1994 Perot-Gore debate over NAFTA on CNN's Larry King Live. Perot protested that U.S. workers were doomed because Mexican workers earned a wage onefifth as high. Gore, obviously primed for that point, shot back that there was nothing to fear at all because Mexican workers were only one-fifth as productive as American workers.

Not merely a talk-show sound-bite, this observation captures an enduring feature of the world economy. We know that fundamental differences in raw worker productivities are a long-standing, ineluctable, feature of the world economy. As Clark (1993) has shown, in 1910 one U.S. textile worker could work as effectively as 1.5 British workers or 6 Indian or Chinese workers. Open trade will make some marginal differences here, but it will not, say, reduce U.S. wage levels to LDC levels and the technology-augmented Heckscher-Ohlin model shows why (Trefler 1993).

Whether globalization broadly construed will lead to convergence in these worker efficiency levels, and whether trade might be one of its channels remains to be seen. How large a role can trade play? One way to put an upper bound on that is to imagine trade acting as a perfect substitute for factor market integration, and to ask what such integration would imply. We know in reality that it is a much less than perfect substitute 
(Collins, O'Rourke, and Williamson 1999), but suppose that the thought experiment stands.

Globalization in factor markets, albeit imperfect, could take us part way toward convergence, since differences in physical/human capital intensity are substantial across countries. Yet, according to Hall and Jones (1999), in the language of " $A k$ " models, the differences in technology (" $A$ ") still account for two thirds of international divergence, and differences capital intensity in (" $k$ ") for only one third. Other place even greater emphasis on " $A$ " (Easterly and Levine 1999). ${ }^{16}$ Since, to some degree, $\mathrm{k}$ is endogenous, given A, this might underestimate the role of "factor convergence" versus "productivity convergence." Several scholars find evidence of both forces working equally strongly for the OECD (Milbourne 1995; Dowrick and Rogers 2001). If these forces were unleashed at a global level at least some of the Great Divergence might finally start to reverse. If trade is a channel for this, or even for transmitting technology convergence, then global inequality may owe more to the lack of trade than to its presence.

\section{Convergence Postponed in the Twentieth Century: Detour or Portent?}

Compared to the very long-run trends in globalization, we can see what an historical aberration twentieth-century economic experience has been: the only sustained period in the last several centuries when trends in the growth of world trade, and globalization more generally, were put into reverse.

Some authors like Polanyi (1944) could write half a century ago with great conviction that indeed we had entered a new age when the global markets would play second fiddle to the state. Now, that statement appears premature, since the very forces that unleashed trade - the economic impulse, the institutional foundations, the technological advances - seem quite durable, even after some of the most disruptive global political shocks history has ever seen. Instead, as we look back on the last century it could be seen as a major hiatus, where the gradual unification of the world economy was put on hold.

Yet, even if technological fundamentals are in place, such as efficient transport infrastructure or essential legal institutions, political will is needed too. The first era of globalization began in an era of highly unrepresentative government, if we look at the world as a whole (Figure 9). Did this make the process any easier? Can today's democratically chosen governments afford the long view? If the gains from trade are there, and the winners adequately compensate the losers in the short run, one might think so. But the history of trade as a development strategy is the story of an evolving process, where winners may appear later, losers perhaps earlier, and the payoffs to innovation may be slow and contingent.

All these factors are at odds with planning horizons dictated more by politics and popular opinion in the short run. That being said, the return toward a more globalized system in

\footnotetext{
${ }^{16}$ In an " $A k$ " model income per capita is $y=A k$, where $A$ is "technology" and $k$ is a measure of composite capital (physical and human) per person. Crucially, all such inputs are accumulable, and show no diminishing returns.
} 
recent years also parallels a rise in representative government, so at the level of raw correlation these problems do not appear overwhelming so far, though the political tensions "on the street" are increasingly palpable.

As the twenty-first century opens we seem close to rejoining, at least in some areas, the trend towards global integration that lasted for several centuries before 1913. This is not to say that a future detour, another serious setback to globalization, will not appear. Yet the past gives us some warnings as to the kind of events that may trigger such a backlash, from geopolitical conflicts and distrust, to economic policies that disregard inclusion by focusing on the winners from globalization and neglecting the losers. We know that our flesh (the technological basis for trade) is strong; our only doubt should be over whether the spirit (the institutional bases determined by political economy) will be allowed to weaken once again.

A successful transition to a globalized world promises more individual freedom, economic and otherwise, and greater opportunities for all in the end, but how we get there from here presents plenty of pitfalls. History tells us how costly distractions can be, but also how and why we should guard against them. 


\section{References}

Angell, Norman. 1910. The Great Illusion. London: W. Heinemann.

Bairoch, Paul. 1972. Free Trade and European Economic Development in the 19th Century. European Economic Review 3:211-45.

Bordo, Michael D., and Hugh Rockoff. 1996. The Gold Standard as a "Good Housekeeping Seal of Approval". Journal of Economic History 56 (2):389-428.

Brezis, E. S. 1995. Foreign Capital Flows in the Century of Britain's Industrial Revolution: New Estimates, Controlled Conjectures. Economic History Review 48 (February): 46-67.

Brezis, Elise S. 1995. Foreign Capital Flows in the Century of Britain's Industrial Revolution: New Estimates, Controlled Conjectures. Economic History Review 48 (1):46-67.

Collins, William J., Kevin H. O’Rourke, and Jeffrey G. Williamson. 1999. Were Trade and Factor Mobility Substitutes in History? In Migration: The Controversies and the Evidence, edited by R. Faini, J. De Melo and K. F. Zimmermann. Cambridge: Cambridge University Press.

Collins, William J., and Jeffrey G. Williamson. 1999. Capital Goods Prices, Global Capital Markets and Accumulation: 1870-1950. Working Paper Series no. 7145, National Bureau of Economic Research (May).

Chiswick, Barry R., and Timothy J. Hatton. 2002. International Migration and the Integration of Labor Markets. In Globalization in Historical Perspective, edited by M. D. Bordo, A. M. Taylor and J. G. Williamson. Chicago: University of Chicago Press.

Crafts, N. F. R. 1985. British Economic Growth during the Industrial Revolution. Oxford: Clarendon Press.

De Long, J. Bradford, and Lawrence H. Summers. 1991. Equipment Investment and Economic Growth. Quarterly Journal of Economics 106 (2):445-502.

Dickson, P. G. M. 1967. The Financial Revolution in England: A Study in the Development of Public Credit, 1688-1756. London: St. Martin's Press.

Dowrick, Steve, and Mark Rogers. 2001. Classical and Technological Convergence: Beyond the Solow-Swan Growth Model: Australian National University, Faculty of Economics and Commerce. Photocopy.

Duncan, Tim, and John Fogarty. 1984. Argentina and Australia: On Parallel Paths. Carlton, Vic.: Melbourne University Press.

Easterly, William, and Ross Levine. 1999. It's Not Factor Accumulation: Stylized Facts and Growth Models. World Bank. Photocopy.

Eichengreen, Barry J., and Douglas A. Irwin. 1995. Trade Blocs, Currency Blocs and the Reorientation of World Trade in the 1930s. Journal of International Economics 38 (1):1-24.

Estevadeordal, Antoni, Brian Frantz, and Alan M. Taylor. 2003. The Rise and Fall of World Trade, 1870-1939 Quarterly Journal of Economics 118. Forthcoming.

Estevadeordal, Antoni, and Alan M. Taylor. 2002. A Century of Missing Trade? American Economic Review 92: 383-93. 
Ferguson, Niall. 2001. The Cash Nexus: Money and Power in the Modern World, 1700-2000. New York: Basic Books.

Findlay, Ronald, and Kevin H. O'Rourke. 2002. Commodity Market Integration, 1500-2000. In Globalization in Historical Perspective, edited by M. D. Bordo, A. M. Taylor and J. G. Williamson. Chicago: University of Chicago Press. Forthcoming.

Fukuyama, F. 1992. The End of History and the Last Man. New York: Free Press.

Glaeser, Edward L., and Andrei Shleifer. 2000. Legal Origins. Harvard University. Photocopy.

Gray, John. 1998. False Dawn: The Delusions of Global Capitalism. London: Granta Books.

Greider, William. 1997. One World, Ready or Not: The Manic Logic of Global Capitalism. New York: Simon \& Schuster.

Greif, Avner. 1993. Contract Enforceability and Economic Institutions in Early Trade: The Maghribi Traders Coalition. American Economic Review 83:525-48.

Greif, Avner. Forthcoming. Genoa and the Maghribi Traders: Historical and Comparative Institutional Analysis. Cambridge: Cambridge University Press.

Greif, Avner, Paul Milgrom, and Barry Weingast. 1994. Coordination, Commitment and Enforcement: The Case of the Merchant Guild. Journal of Political Economy 102:745-76.

Hall, Robert E., and Charles I. Jones. 1999. Why Do Some Countries Produce So Much More Output per Worker than Others? Quarterly Journal of Economics 114 (1):83-116.

Hertz, Noreena. 2001. The Silent Takeover: Global Capitalism and the Death of Democracy. London: Heinemann.

Huntington, Samuel P. 1996. The Clash of Civilizations and the Remaking of World Order. New York: Simon \& Schuster.

Jones, Charles I. 1994. Economic Growth and the Relative Price of Capital. Journal of Monetary Economics 34 (December):359-82.

Jones, Eric L. 1981. The European Miracle. Cambridge: Cambridge University Press.

Klein, Naomi. 1999. No Logo: Taking Aim at the Brand Bullies. Toronto: Vintage Canada.

Landes, D. S. 1969. The Unbound Prometheus: Technological Change and Industrial Development in Western Europe from 1750 to the Present. Cambridge: Cambridge University Press.

Lindert, Peter H., and Jeffrey G. Williamson. 2002. Does Globalization Make the World More Unequal? In Globalization in Historical Perspective, edited by M. D. Bordo, A. M. Taylor and J. G. Williamson. Chicago: University of Chicago Press. Forthcoming.

López-Córdova, J. Ernesto, and Chris Meissner. Exchange-Rate Regimes and International Trade: Evidence from the Classical Gold Standard Era. American Economic Review. Forthcoming.

Matsuyama, Kiminori. 1992. Agricultural Productivity, Comparative Advantage, and Economic Growth. Journal of Economic Theory 58:317-34. 
McLean, Ian W., and Alan M. Taylor. 2001. Australian Growth: A California Perspective. Working Paper Series no. 8408, National Bureau of Economic Research (August).

Micklethwait, John, and Adrian Wooldridge. 2000. A Future Perfect: The Challenge and Hidden Promise of Globalization. New York: Crown Business.

Milbourne, Ross. 1995. Factor Convergence Versus Productivity Convergence. University of New South Wales. Photocopy.

Monbiot, George. 2000. Captive State: The Corporate Takeover of Britain. London: Macmillan.

Moselle, Boaz, and Benjamin Polak. 2001. A Model of a Predatory State. Journal of Law, Economics and Organization.

Neal, Larry. 1990. The Rise of Financial Capitalism: International Capital Markets in the Age of Reason. Cambridge: Cambridge University Press.

North, Douglass C., and Barry R. Weingast. 1989. Constitutions and Commitment: The Evolution of Institutions Governing Public Choice in Seventeenth-Century England. Journal of Economic History 49 (4):803-32.

O’Brien, Patrick K. 1998. Inseparable Connections: Trade, Economy, Fiscal State and the Expansion of Empire, 1688-1815. In The Oxford History of the British Empire, edited by W. R. Louis, A. M. Low, N. P. Canny and P. J. Marshall. Oxford: Oxford University Press.

O'Rourke, Kevin H. 2000. Tariffs and Growth in the Late 19th Century. Economic Journal 110:456-83.

O’Rourke, Kevin H., Alan M. Taylor, and Jeffrey G. Williamson. 1996. Factor Price Convergence in the Late Nineteenth Century. International Economic Review 37 (3):499-530.

O'Rourke, Kevin H., and Jeffrey G. Williamson. 1999. Globalization and History: The Evolution of a Nineteenth-Century Atlantic Economy. Cambridge: MIT Press.

O'Rourke, Kevin H., and Jeffrey G. Williamson. 2002a. After Columbus: Explaining the European Overseas Trade Boom 1500-1800. Journal of Economic History. Forthcoming.

O'Rourke, Kevin H., and Jeffrey G. Williamson. 2002b. The Heckscher-Ohlin Model Between 1400 and 2000: When It Explained Factor Price Convergence, When It Didn't, And Why. In Bertil Ohlin: A Centennial Celebration, 1899-1999, edited by R. Findlay, L. Jonung and M. Lundahl. Cambridge, Mass.: MIT Press. Forthcoming.

O'Rourke, Kevin H., and Jeffrey G. Williamson. 2002c. When Did Globalization Begin? European Review of Economic History. Forthcoming.

Obstfeld, Maurice, and Alan M. Taylor. 2003. Globalization and Capital Markets. In Globalization in Historical Perspective, edited by M. D. Bordo, A. M. Taylor and J. G. Williamson. Chicago: University of Chicago Press.

Olson, Mancur, Jr. 2000. Power and Prosperity: Outgrowing Communist and Capitalist Dictatorships. New York: Basic Books.

Polanyi, Karl. 1944. The Great Transformation. New York: Rinehart.

Pomeranz, Kenneth. 2000. The Great Divergence: Europe, China, and the Making of the Modern World Economy. Princeton, N.J.: Princeton University Press. 
Rodriguez, Francisco, and Dani Rodrik. 2001. Trade Policy and Economic Growth: A Skeptic's Guide to Cross-National Evidence. In NBER Macroeconomics Annual 2001, edited by B. S. Bernanke and K. Rogoff.

Rodrik, Dani. 2001. The Global Governance of Trade as if Development Really Mattered. Photocopy.

Rogowski, Ronald. 1989. Commerce and Coalitions: How Trade Affects Domestic Political Alignments. Princeton, N.J.: Princeton University Press.

Rose, Andrew K. 2000. One Money, One Market: The Effect of Common Currencies on Trade. Economic Policy 15 (30):7-33.

Rousseau, Peter L., and Richard E. Sylla. 2002. Financial Systems, Economic Growth, and Globalization. In Globalization in Historical Perspective, edited by M. D. Bordo, A. M. Taylor and J. G. Williamson. Chicago: University of Chicago Press. Forthcoming.

Sachs, Jeffrey D., and Andrew M. Warner. 1995. Economic Reform and the Process of Global Integration. Brooking Papers on Economic Activity (1):1-118.

Taylor, Alan M. 1994. Tres fases del crecimiento económico argentino. Revista de Historia Económica 12 (3):649-83.

Taylor, Alan M. 1995. Debt, Dependence, and the Demographic Transition: Latin America into the Next Century. World Development 23 (5):869-79.

Taylor, Alan M. 1998a. Argentina and the World Capital Market: Saving, Investment, and International Capital Mobility in the Twentieth Century. Journal of Development Economics 57 (1):147-84.

Taylor, Alan M. 1998. On the Costs of Inward-Looking Development: Price Distortions, Growth, and Divergence in Latin America. Journal of Economic History 58 (1):1-28.

Trefler, Daniel. 1993. International Factor Price Differences: Leontief Was Right! Journal of Political Economy 101 (6):961-87.

Vamvakidis, Athanasios. 1997. How Robust is the Growth-Openness Connection? Historical Evidence. Harvard University. Photocopy.

Williamson, Jeffrey G. 1990. The Impact of the Corn Laws Just Prior to Repeal. Explorations in Economic History 27 (2):123-56.

Williamson, Jeffrey G. 2002. Land, Labor, and Globalization in the Pre-Industrial Third World. Journal of Economic History. Forthcoming.

Wood, Adrian. 1994. North-South Trade, Employment, and Inequality: Changing Fortunes in a Skill-Driven World. Oxford: Clarendon Press.

Wright, Gavin. 1990. The Origins of American Industrial Success, 1879-1940. American Economic Review 80 (4):651-68. 
Figure 1

International Trade as a Percentage of GDP Since 1800

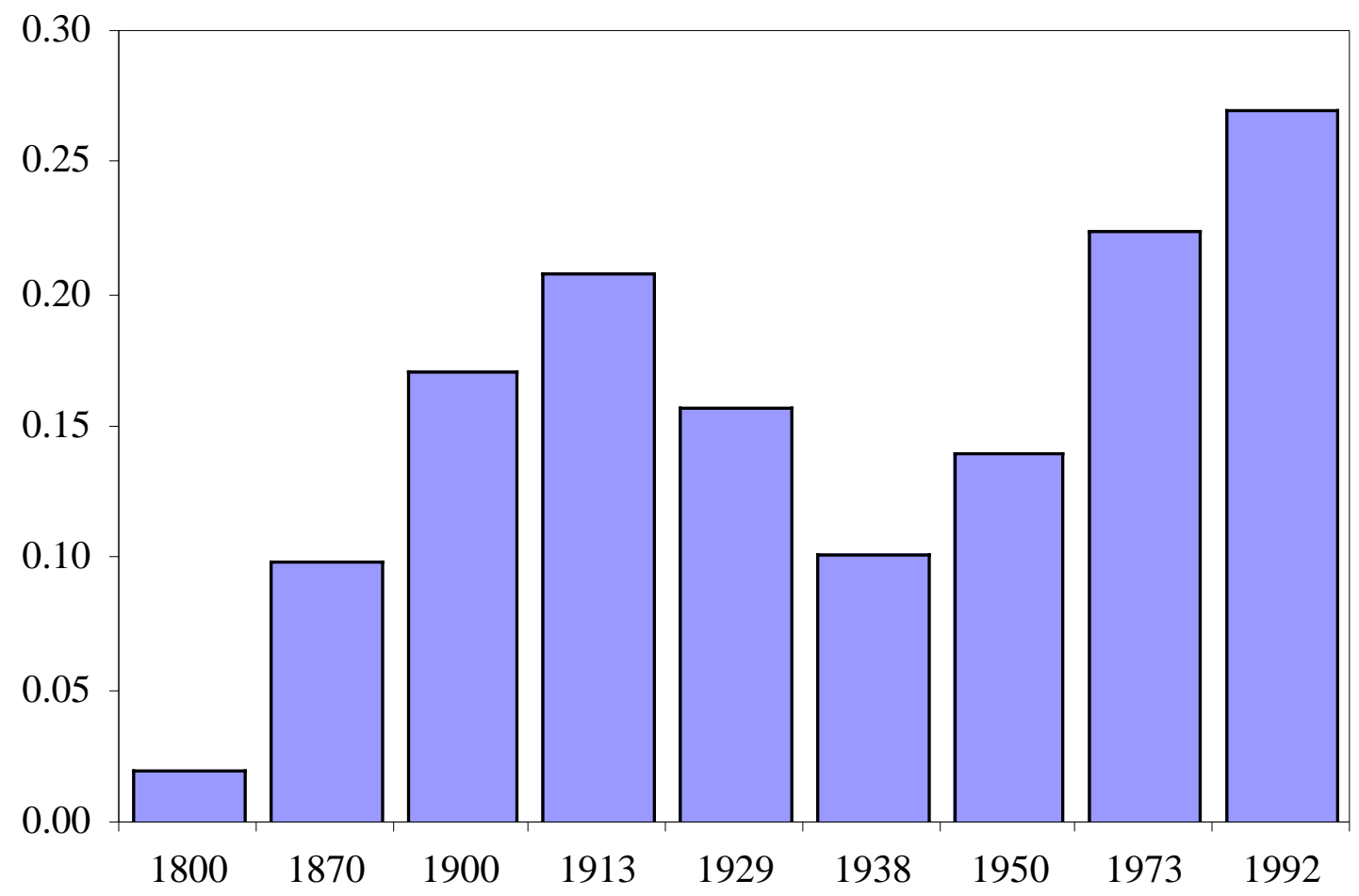

Notes: Exports plus imports divided by output.

Source: Estevadeordal, Frantz, and Taylor (2003). 
Figure 2

International Investment as a Fraction of GDP Since 1870

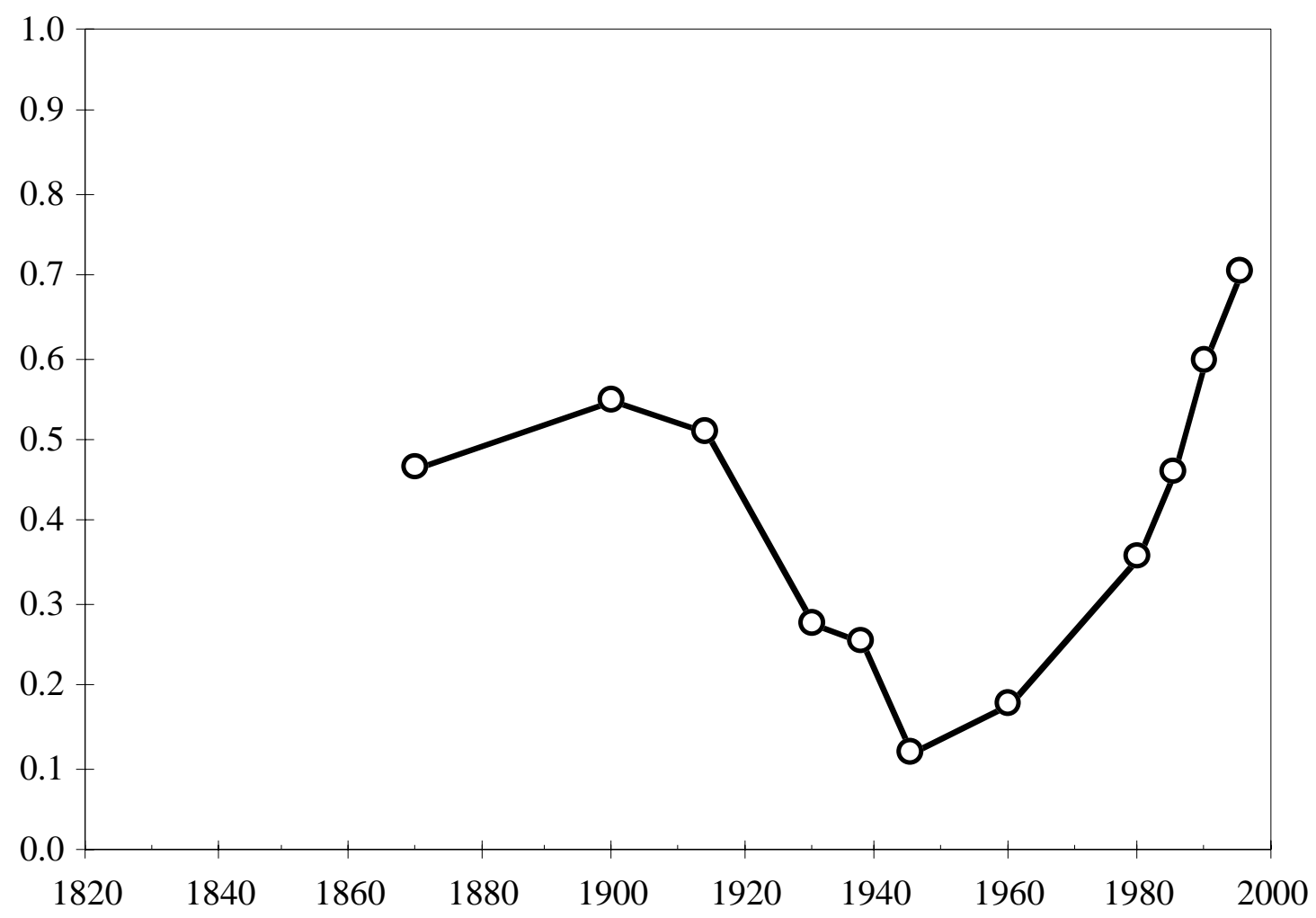

Source: Obstfeld and Taylor (2003). 
Figure 3

All of Globalization and History on One Diagram

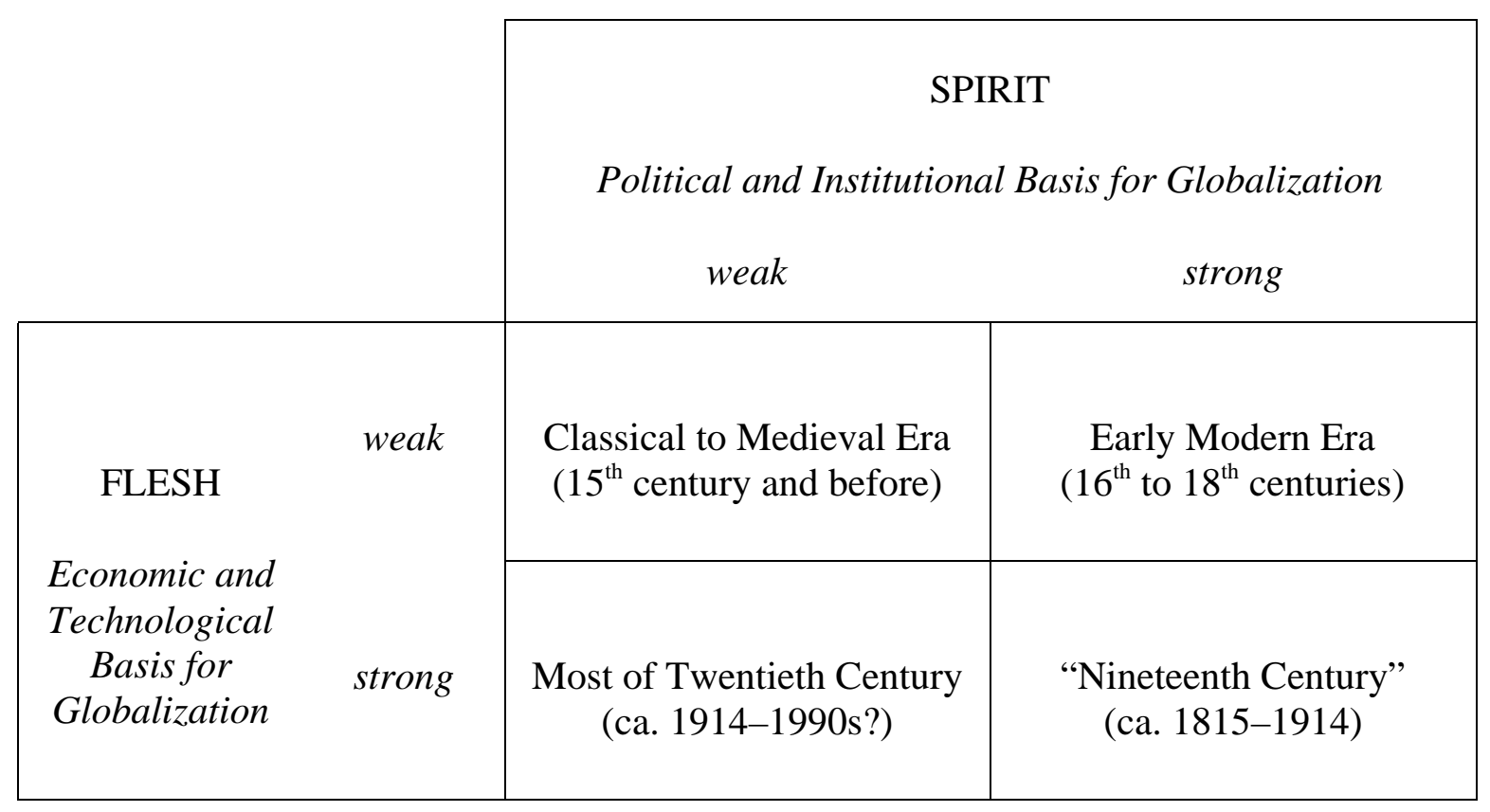


Figure 4

Spice and Coffee Markups: Amsterdam vs. Southeast Asia 1580-1939

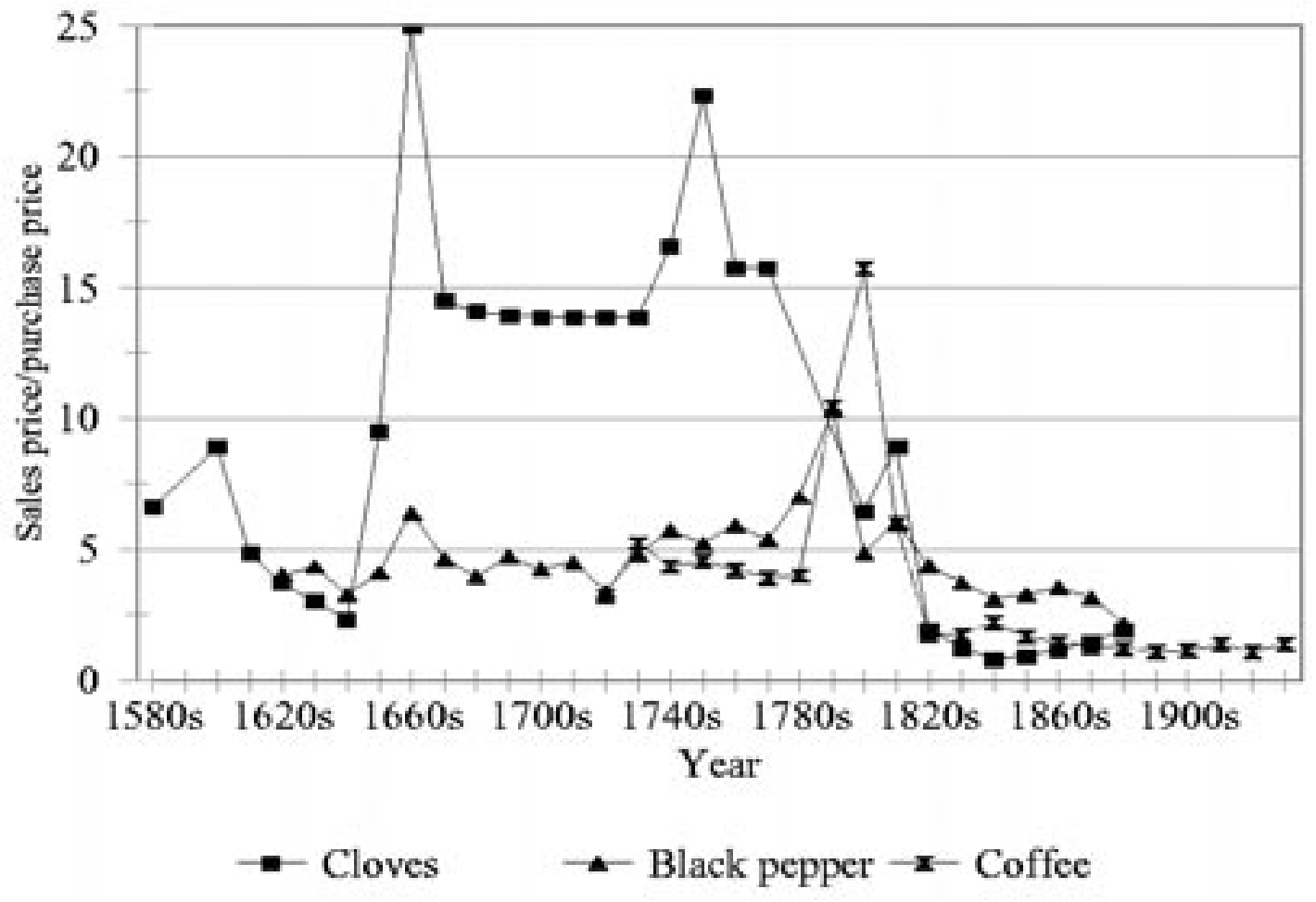

Source: O'Rourke and Williamson (2002c). 
Figure 5

Freight Rates on Cotton, Egypt and U.S. to the Britain, 1870-1914

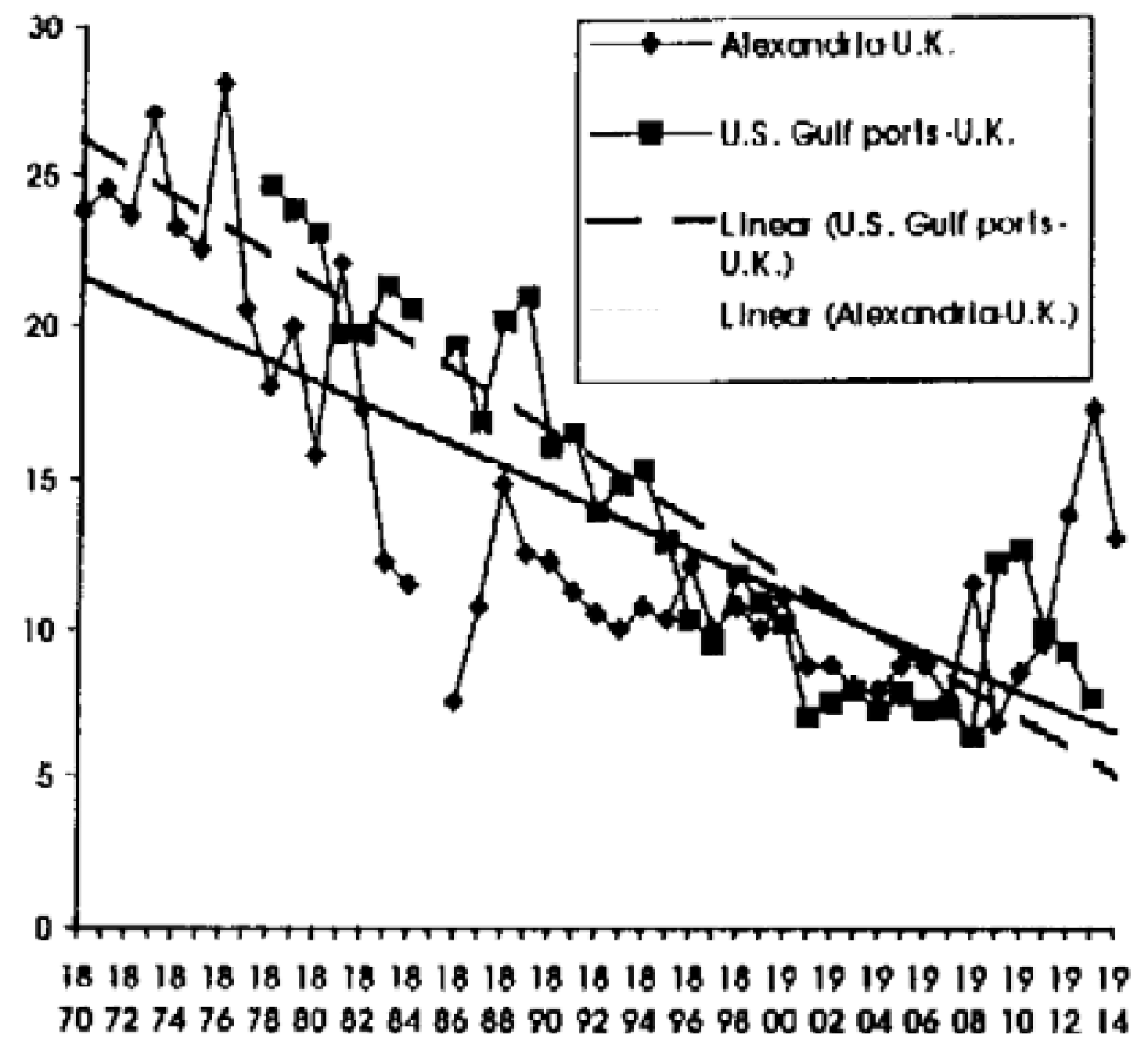

Source: O'Rourke and Williamson (2002b). 
Figure 6

Resources and Comparative Advantage circa 1910

Capital

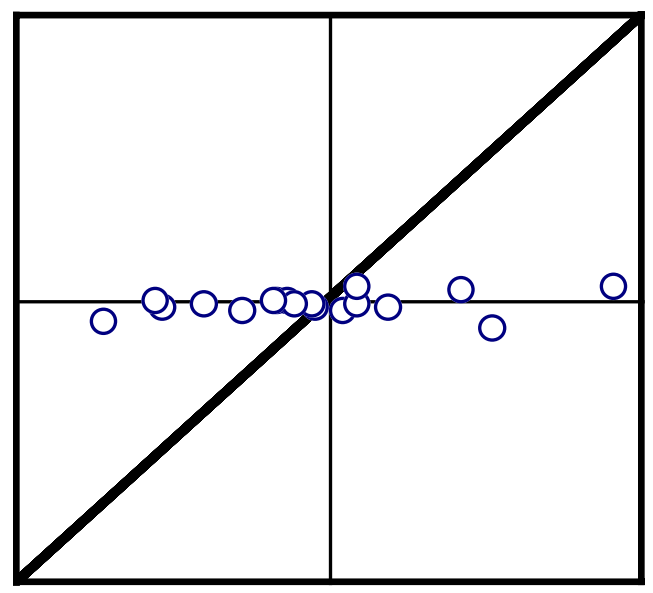

Resources-Renewable

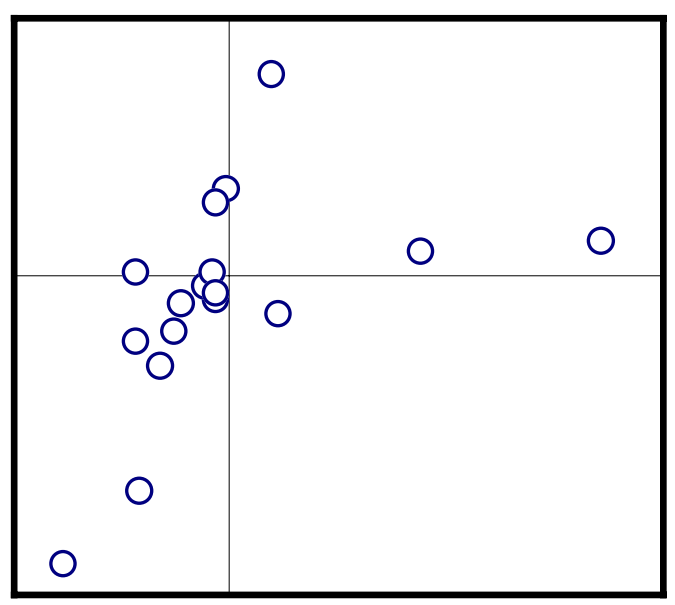

Labor

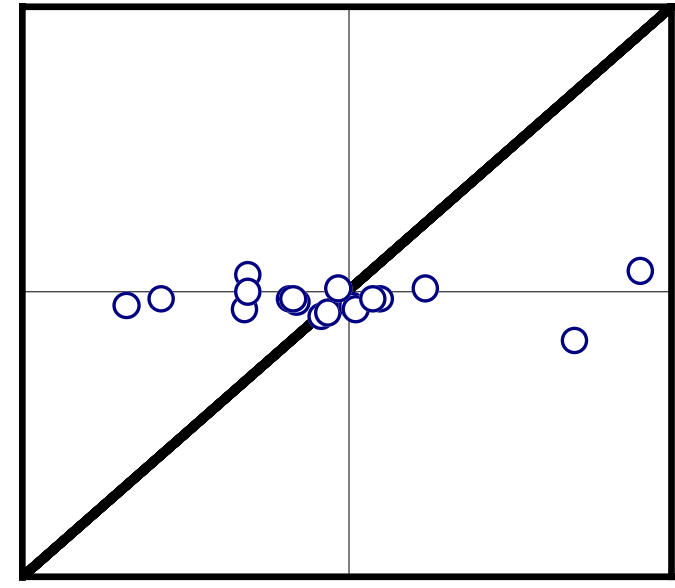

Resources-Nonrenewable

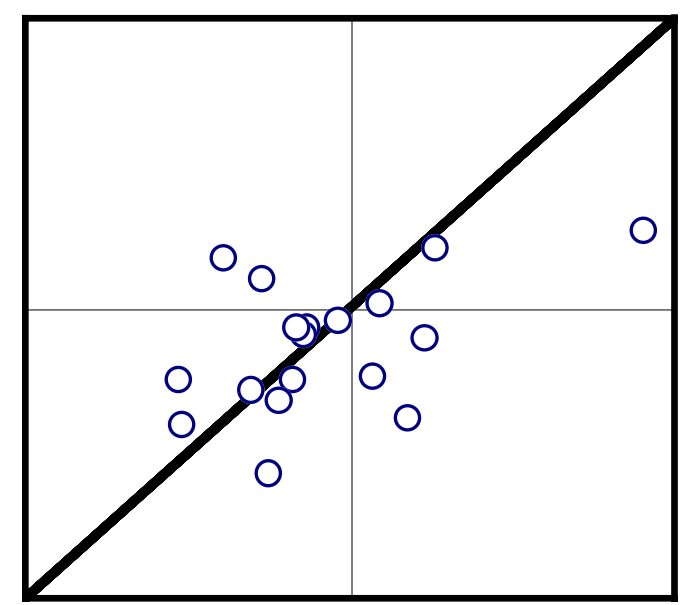

Source: Estevadeordal and Taylor (2002). 
Figure 7

Relative price of capital, five countries, 1870-1950

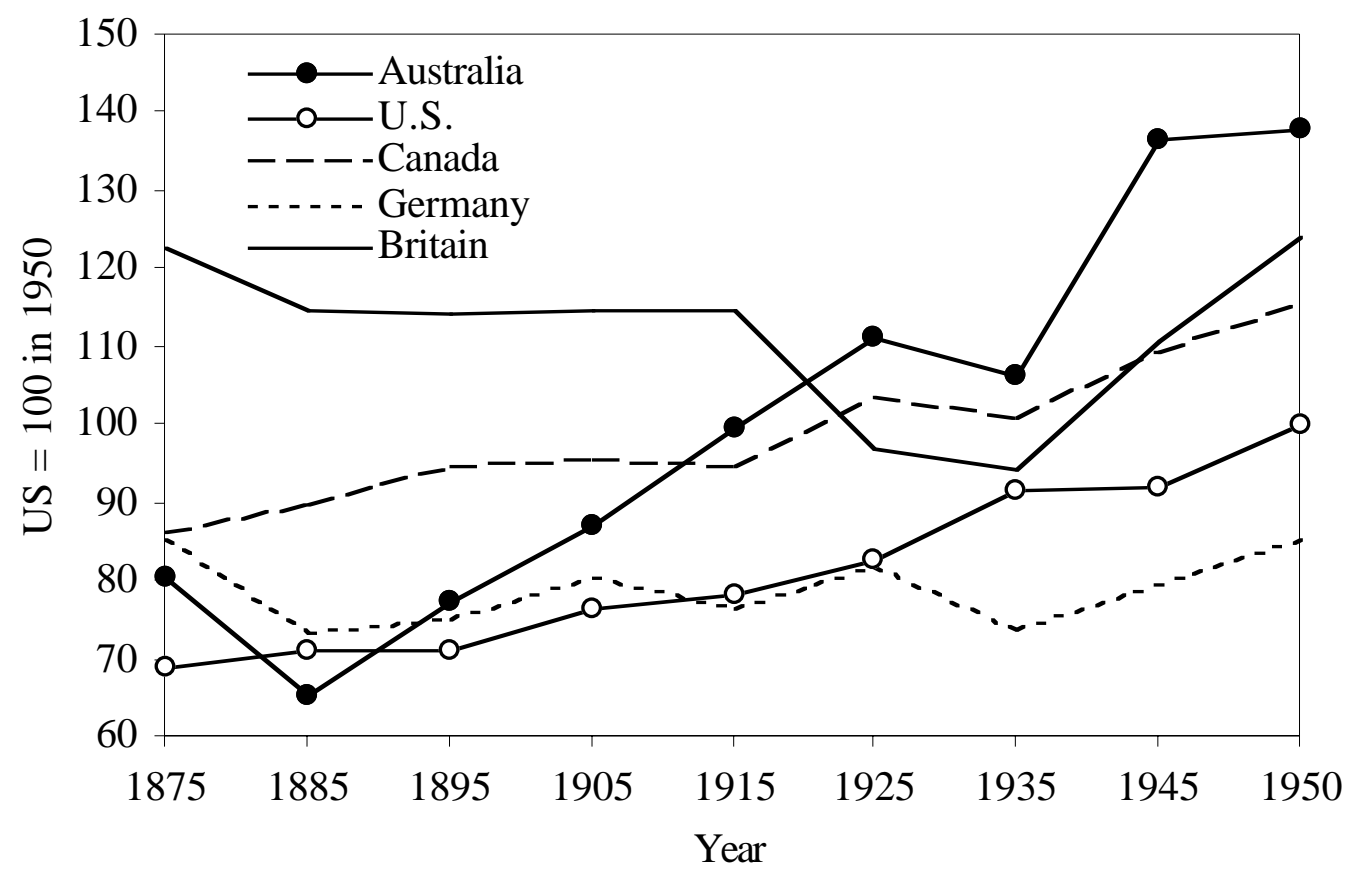

Source: McLean and Taylor (2001). 
Figure 8

Global Inequality Since 1800

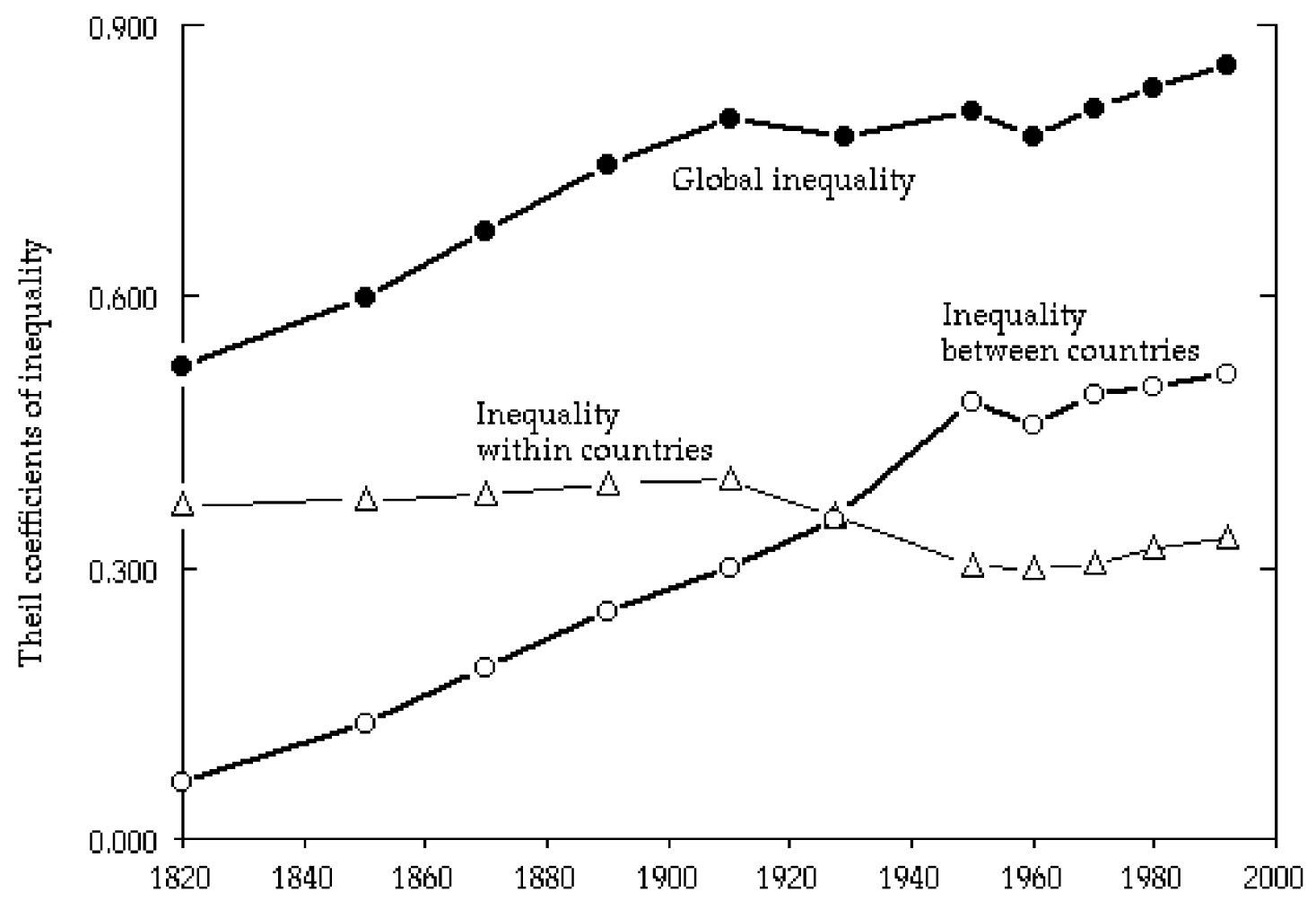

Source: Lindert and Williamson (2002). 
Figure 9

The Rise of Democracy since 1800

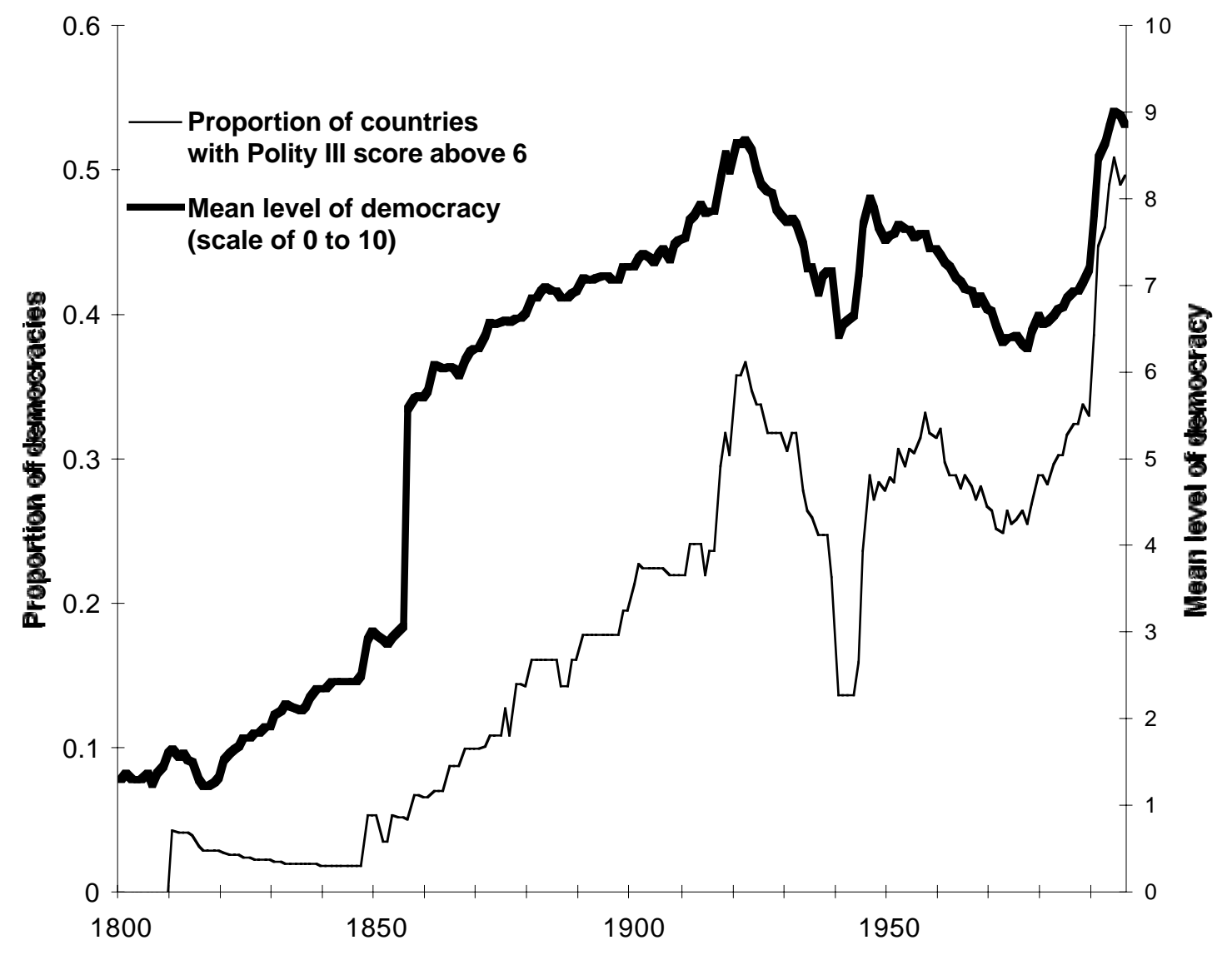

Source: Polity III Database (Jaggers and Gurr 1995), courtesy of Niall Ferguson and Michael Ward. 